\title{
"Quasi-Community Property" in the Contlict of Laws
}

\section{Herma Hill Schreter*}

SINCE gold-rush days, California has been vexed with problems of apply$\mathcal{S}$ ing her civil-law community property system to newcomers from common-law states. Delegates to the state constitutional convention who were trained in common-law doctrines of marital property succeeded in writing a "married woman's property act" into the California Constitution of 1849. . However much it was to be desired for wives in common-law states, such remedial legislation was inconsistent with a community property system. The upshot of this initial encounter between the two systems was to set California on a path that has left her with a hybrid marital property law nearly as foreign to other community property states as it is to the common-law states. ${ }^{2}$

Subsequent encounters between the two systems were caused by married couples who came to California from common-law states with property acquired in their former domiciles. When these marriages ended in divorce or death, California courts were called upon to dispose of the marital acquisitions. Although California permits husbands and wives to hold property in several different ways, ${ }^{3}$ their interests must ultimately be classified in keeping with community property doctrine as either community or separate. ${ }^{4}$ Common-law property, however, does not fit neatly into either of these categories. The common-law system has no counterpart for the civillaw concept of separate property, which is defined as all property owned before marriage, and property acquired after marriage by gift, bequest, devise, or descent. ${ }^{5}$ In nearly all common-law states women acquire valuable rights in property already owned or thereafter acquired by their husbands. ${ }^{\circ}$ Such property is not immune from the wife's potential marital claims merely by virtue of the time $e^{7}$ or method ${ }^{8}$ of its accumulation. But

* Acting Assistant Professor of Law, University of Cahifornia School of Law, Berkeley.

1 Cal. Const. art. XXI, \&14 (1849); George v. Ransom, 15 Cal. 322 (1860).

2 McMurray, The Beginnings of the Community Property System in California and the Adoption of the Common Law, 3 CaLIf. L. Rev. 359 (1915). See 1 Ararstrono, Catifornia FammL LaW 431-32 (1953) [heremafter cited as Armstrong].

3 CaL. Crv. Code $\$ 161$.

4 Siberell v. Siberell, 214 Cal. 767, 7 P.2d 1003 (1932).

5 Car. Crv. Code $\$ \$ 162,163$.

6 Marse, Marital Property in Confutct of LaWs 11-67 (1952) [heremafter cited as MARSH].

7 The California courts did not, however, appreciate this difference. See Estate of Higgins, 65 Cal. 407, 4 Pac. 389 (1884).

8 MaRSH 43-45, 226; Leflar, Conzmunity Property and Conflict of Laws, 21 CarIF. L. REv. 221, 226-27 (1933). 
in no common-law state can a wife set aside her husband's unilateral good faith conveyance of his personal property merely because the conveyance was made without consideration. ${ }^{9}$ Nor does a common-law wife who predeceases her husband have testamentary control over any part of his acquisitions. ${ }^{10}$ On the other hand, the California wife possesses both these powers over community property, although she receives no rights by marriage in the separate property of her husband. Since 1891 she has had the power to set aside her husband's gifts of community property, ${ }^{11}$ and simce 1923 she has had the power to dispose of one-half the community property by will. ${ }^{12}$

Wives coming to California urged that the community property concept was California's closest approximation to common-law ideas of marital property, while their husbands sought a classification of all common-law property as separate property. Unfortunately, the California courts accepted the latter position. They reasoned that since the wife in commonlaw states lacked the power to set aside her husband's good faith conveyances of his personal property, her marital interest was a "mere expectancy" and not a "vested" interest. ${ }^{13}$ Their analysis ignored the fact that the California wife's possession of such a power over her husband's transfers of community property did not create a "vested" interest in her as to that property. ${ }^{14}$ Since the prevailing conflict of laws doctrine indicated that a mere change in domicile did not change "vested" interests in property, ${ }^{15}$ the decision that the wife did not "own" any of the personal property acquired by her husband in the common-law state led the California courts to classify that property as the separate property of the husband. ${ }^{16}$ The rules pertaining to disposition of California separate property on death or divorce were then applied to the common-law property.

9 Marsh 34-37, nn.90, 100-05.

10 MARSH 46.

11 CaL. Crv. Code $\$ 172$.

12 Cas. Prob. Code $\$ 201$.

13 Estate of O'Connor, 218 Cal. 518, 23 P.2d 1031 (1913); Estate of Nickson, 187 Cal. 603, 607, 203 Pac. 106, 108 (1921); Estate of Burrows, 136 Cal. 113, 115-16, 68 Pac. 488, 489 (1902) (Temple, J., concurring); cf. Paley v. Bank of America, 159 Cal. App. 2d 500, 506, 324 P.2d 35, 39 (1958). The testamentary control provision of Probate Code $\S 201$ also would have supported the court's reasoning, but it had not been adopted at the time this position was formulated.

14 Spreckles v. Spreckles, 172 Cal. 775, 782, 158 Pac. 537, 539 (1916). Nor did her later acquired testamentary control give her a "vested" interest in the community property. Trimble v. Trimble, 219 Cal. 340, 345-47, 26 P.2d 477, 479-80 (1933).

15 Kraemer v. Kraemer, 52 Cal. 302 (1877), the leading Califorma case, relies upon Story and Wharton for this primciple. See STORY, ConfuTCr OF Laws $\$$ 183-87 (4th ed. 1852); Wharton, Confutct of Laws $\$$ 196-98 (2d ed. 1881). The Kraemer case and the California cases following it in turn establish the rule for subsequent treatises. BALIINGER, CoMrMunItX Property § 47 (1895); 2 Beale, Conflict of Laws \$§ 292.1-93.2 (1935).

16 E.g., Estate of Arms, 186 Cal. 554, 563-64, 199 Pac. 1053, 1056-57 (1921). See also cases cited note 13 supra. 
When wives from common-law states attempted upon dissolution of the marriage to secure for themselves a possessory interest in their husband's marital acquisitions, they were defeated at every turn. If the property was real property located in California, so that the wife could urge application of California law as the lex situs, ${ }^{17}$ the courts traced the funds used to purchase the land to personal property acquired by the husband in a commonlaw state. ${ }^{18}$ Since that property was his "separate" property, and since California wives do not share in their husbands' separate property on divorce or, if he died leaving an unfavorable will, on death, the wife from a commonlaw state was similarly prevented from sharing in the land on death ${ }^{10}$ or divorce. ${ }^{20}$

The same argument followed from the same reasoning for personal property, whether the chattel involved had itself been brought to California $^{21}$ or had been acquired in California in exchange for the original property. ${ }^{22}$ On the husband's death, this result would also apply to personal property remaining in the common-law state, since the devolution of movables is said to be determined by the law of the decedent's last domicile-

17 Restatement, Conflict of Laws $\$ \$ 238,249$ (1934); Restatement (Second), ConFLICT of Laws $\S \S 238,249$ (Tent. Draft No. 5,1959 ). It has been pointed out that this rule need not be taken seriously since courts at the situs usually look to the character of the property used to acquire the real estate and preserve in the land the marital property interests attributed to the original property. Marse 189-92. The Restatement Second, although insisting upon its former black-letter wording, now itself enjoins the courts of the situs to employ the tracing technique. Restatement (SECOND), Conflict of Laws § 238, cominent $a$ (Tent. Draft No. 5, 1959).

18 No distinction is drawn by the courts between the case in which the husband sent money from a common-law state to purchase realty in California, e.g., Estate of Warner, 16 ' Cal. 686, 140 Pac. 583 (1914), and the case in which he sold real estate owned by him in a common-law state and used the proceeds to buy real estate in California, e.g., Estate of Nickson, 187 Cal. 603, 203 Pac. 106 (1921). No case has been found involving a direct exchange of common-law real property for community real property.

19 Estate of Nickson, 187 Cal. 603, 203 Pac. 106 (1921) ; Estate of Niccolls, 164 Cal. 368, 129 Pac. 278 (1912); Estate of Burrows, 136 Cal. 113, 68 Pac. 488 (1902). When the husband died domiciled in a common-law state, the California courts characterized his California realty as separate property because its source was common-law purchase money. Estate of Arms, 186 Cal. 554, 199 Pac. 1053 (1921); Estate of Warner, 167 Cal. 686, 140 Pac. 583 (1914). The same characterization results fron Probate Code $\$ 201.6$, enacted in 1957 to govern testamentary dispositions of California realty by non-domiciliary decedents. However, the wife may get more under $\$ 201.6$ than she got under Warner and Arms, supra, because the section recognizes the distimction between the concepts of separate property in a common-law state and in a community property state, a distinction that the cases failed to grasp. See MarSH 27-50. It should be added that if the 1961 amendenent is upheld on this point, Burrows and Niccolls, supra, will be reversed on their facts. See CAI. PROB. CODE $\$ 661$.

20 Kraemer v. Kraeiner, 52 Cal. 302 (1877).

21 Estate of Thornton, 1 Cal. 2d 1, 33 P.2d 1 (1934); Estate of Drishaus, 199 Cal. 369, 249 Pac. 515 (1926) ; Estate of Frees, 187 Cal. 150, 201 Pac. 112 (1921) ; Estate of Boselly, 178 Cal. 715, 175 Pac. 4 (1918).

22 Estate of O'Counor, 218 Cal. 518, 23 P.2d 1031 (1933); cf. Shumway v. Leakey, 67 Cal. 458, 8 Pac. 12 (1885). 
in this case, California. ${ }^{23}$ In the divorce case, of course, personal jurisdiction over the husband would permit application of California law to prevent the division of his "separate" personal property left behind in the commonlaw state. Thus, the wife forfeited whatever protections she had been accorded by her prior domicile. ${ }^{24}$

California made an all-or-nothing effort to solve this problem in 1917 by extending community property rights to wives from common-law states. To accomphish this end, the legislature denominated as community property real property situated in California, and personal property, wherever situated, that would have been community property had it been acquired by a nuarried person domiciled in Califorma. ${ }^{25}$ The statute was declared unconstitutional in 1934 in Estate of Thornton. ${ }^{28}$ Abandoning the attempt to do the job in a comprehensive fashion, the legislature confined itself to determining the devolution of the property after death. ${ }^{27}$ The success of this approach following its revision in $1957^{28}$ encouraged ${ }^{29}$ the legislature to approach in 1961 other carefully selected aspects of marital property

23 Cf. Estate of O'Connor, 218 Cal. 518, 23 P.2d 1031 (1933) (wife's argument for application of the law of the place of acquisition rejected, but property had been removed to Califormia); Marse 226-33; Restateanent, Conflict of Laws $\$ \S 303,306$ (1934). California now specifically applies her own law to personal property wherever situated if the decedent died domiciled in California. CAx. Prob. CoDE $\$ \S 201.5,201.8$ (1957). The Restatement Second distinguishes between tangible and intangible novables, referring problems relating to the forner to the law of the situs only when that law is contrary to the otherwise governing law of the domicile at death. Restatement (SECOND), Conflict of Laws $\$$ 303, 306 (Tent. Draft No. 5, 1959). The drafters have largely nullified their new distinction by endorsing the "generally accepted common law rule" requiring the situs to defer to the domicile at death. Id. $\$ 303$, comments $a$ and $c ; \S 306$, comments $c, d$, and $e$. See generally ExRENzweig, Confuict of Laws PART II \& 246 (West Publishing Co., forthcoming).

24 An argument could have been made for preserving the wife's dower rights in real property acquired while domiciled in the common-law state. As Professor Marsb states, the change of domicile does not change the marital property interests in real property left behind. MARSE 203-04. The Restatement Second, relying upon the "unanimous support of all pertinent authority," states that the law of the situs governs intestate succession to land. RESTATEMIENT (SECOND), CoNfurct of LAws $\$ 245$ (Tent. Draft No. 5, 1959). This position, although without the sweepmg citation, extends to questions of the validity and effect of a will of land. Id. at $\$ 249$. Thus, the change of domicile should not affect the wife's succession rights under the law of the situs.

25 Cal. Stat. 1917 ch. 581, at 827 (amending CAL. Crv. CoDE § 164).

281 Cal. 2d 1, 33 P.2d 1 (1934).

27 Cal. Stat. 1935 ch. 831, at 2248 (adding CAL. Prob. Code $\$ 201.5$ ).

28 Cal. Stat. 1957 ch. 490 , at 1520 (amending CAL. ProB. CodE $\S 201.5$ and adding $\$ \S 201.6$, 201.7, 201.8). For a detailed discussion of this legislation, see Abel, Barry, Halsted \& Marsh, Right of a Strviving Spouse in Property Acquired by a Decedent While Domiciled Outside California, 47 CarT. L. Rev. 211 (1959).

20 The California Law Revision Commission requested and received permission to study the inter vivos problems after the succession study was completed. CaLIFORNIA LAw REvision Comarin, Recomatendation and Study Retattng to Inter Vivos Marttat Property Rights

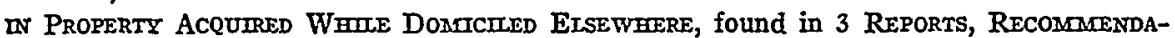
Trons \& STUDIEs (1961) [hereinafter cited as Law Comm's Srudy]; see Abel, Barry, Halsted \& Marsh, sztpra note 28, at 235-36. 
law: division of the community property upon divorce or separation, and homestead problems. ${ }^{30}$

This paper will examine the 1961 enactment from two points of view. The unfortunate decision in Estate of Thornton has apparently discouraged the legislature from attempting to reclassify according to community concepts all property acquired in common-law states by persons who subsequently become domiciliaries of California. The first section of this paper will attempt to remove that inhibition by suggesting that the Thornton decision was unnecessary as a matter of constitutional law. The 1961 legislation, however, is not limited to property acquired by persons who become Californians. Indeed, it literally applies to all real property located in California and personal property wherever located. The second part of this paper will discuss conflict of laws problems suggested by the conjunction of the statute's broad language with the selection of divorce, separate maintenance, and declaration of homesteads as the critical events for reclassification.

\section{I}

THE UNDERLYING PROBLEM: Estate of Thornton

Mr. and Mrs. Thornton were domiciled in Montana from 1885 to 1899 and again from 1906 to 1919 . During these periods, Mr. Thornton accumulated property that became his estate when he died domiciled in California in 1929. His will made no provision for his wife, and she claimed against it. She asserted that she was entitled to one-half of his estate on the theory that the 1917 amendment to Civil Code section 164 defined the property as community and that Probate Code section 201 gave her, as the surviving spouse, one-half of the community property. This theory (which, as one of the briefs for Mrs. Thornton pointed out, counsel for the estate obscured by their broad constitutional attack $^{31}$ ) necessitated a decision only about

30 Cal. Stat. 1961 ch. 636, at 1838. The statute makes the following changes in the California Codes: Car. Crv. CoDE $\$ \$ 140.5,140.7,1237.5$ (new) ; 141, 142, 143, 146, 148, 149, 164, 176, 1238, 1265 (amended). CaI. Prob. Code $\$ \$ 201.5,661,663$ (amended). Cal. Rev. \& Tax. Code $\$ \S 13672,15300,15302.5,15303.5$ (new); 15301, 15306 (amended). Civil Code $\$ 140.7$ defines quasi-commumity property as:

all personal property wherever situated and all real property situated in this State heretofore or hereafter acquired: (a) By either spouse while domiciled elsewhere which would have been commumity property of the husband and wife had the spouse acquiring the property been domiciled in this State at the time of its acquisition; or (b) In exchange for real or personal property, wherever situated, acquired other than by gift, devise, bequest or descent by either spouse during the marriage while domiciled elsewhere.

See generally Selected 1960-1961 California Legislation, 36 CAC. S.B.J. 643, 672 (1961).

${ }^{31}$ Appellant's Petition for Rehearing, pp. 2-8, Estate of Thornton, 1 Cal. 2d 1, 33 P.2d 1 (1934). 
the validity of the succession statute, not about section 164's potential restrictions on the husband's inter vivos rights in the property. The court, however, refused to limit the issue. Both in its original opinion, ${ }^{32}$ which held the statute constitutional, and in its later decisive opinion on rehearing, ${ }^{33}$ which held the statute unconstitutional, the court considered the general problem of reclassifying common-law property according to community concepts during the lifetinie of both spouses.

Two,principles were relied upon in reaching the conclusion of the second opinion. First, the majority reasoned from the holding of Spreckles $v$. Spreckles ${ }^{34}$ that amendments to the community property statutes decreasing the husband's powers of managenient and control over the community property apply only to subsequently acquired property. Second, they relied upon the unbroken line of decisions establishing that property brought to California from a common-law state does not thereby acquire a community status. ${ }^{35}$ Pointing out that the court had previously held that the new amendment did not operate retroactively, ${ }^{36}$ the majority concluded that the statute violated both the privileges and immunities and due process clauses of the fourteenth amendmient. The former applied because if the retroactive application of laws changing a California husband's powers im previously-acquired property unconstitutionally deprived hinl of a vested property right, ${ }^{37}$ then application of a California statute changing a comnion-law husband's powers in property acquired elsewhere and brought to California "is clearly to abridge the privileges and immunities of the citizen." ${ }^{38}$ The latter clause applied because, apparently as a self-evident principle, "to take the property of A and transfer it to $\mathrm{B}$ because of his citizen-

32 In re Thornton's Estate, 19 P.2d 778 (1933).

33 Estate of Thornton, 1 Cal. 2d 1, 33 P.2d 1 (1934).

34116 Cal. 339, 48 Pac. 228 (1897).

85 The court cited Estate of Boselly, 178 Cal. 715, 175 Pac. 4 (1918) ; Estate of Niccolls, 164 Cal. 368, 129 Pac. 278 (1912); Estate of Burrows, 136 Cal. 113, 68 Pac. 488 (1902); Kraemer v. Kraemer, 52 Cal. 302 (1877).

36 Estate of Drishaus, 199 Cal. 369, 249 Pac. 515 (1926). The retroactivity issue was raised in Estate of Frees, 187 Cal. 150, 201 Pac. 112 (1921), but the legislature had not at that time made the statute expressly retroactive, and the case was decided on the basis that the legislature did not intend retroactive application. See also Estate of Arms, $186 \mathrm{Cal} .554,199$ Pac. 1053 (1921). The legislative intention was clarified by the 1923 amendment to Civil Code $\S 164$. Cal. Stat. 1923 ch. 360 , at 746.

37 The Spreckles doctrine applies not only to property acquired prior to the effective date of the amendment, but also to any subsequently acquired property traceable to the previously held property. Boyd v. Oser, 23 Cal.2d 613, 145 P.2d 312 (1944). For critical discussion of the Spreckles doctrine, see Armstrong, "Prospective" Application of Changes in Community Property Control-Rule of Property or Constitutional Necessity?, 33 CALIF. L. REv. 476 (1945); Comment, Conmunity and Separate Property: Constitutionality of Legislation Decreasing Husband's Power of Control Over Property Already Acquired, 27 CAIIF. L. REv. 49 (1938).

38 Estate of Thornton, 1 Cal. 2d 1, 5, 33 P.2d 1, 3 (1934). 
ship and domicile, is also to take his property without due process of law." It would seem that as far as the court was concerned, the conclusion was compelled by precedent, analogy, and a common understanding of the concept of due process of law.

Spreckels v. Spreckles, ${ }^{40}$ which figures so prominently in the Thornton reasoning, involved the first major amendment decreasing the power of the husband to manage and control the coinmumity property. ${ }^{41}$ Prior to March 31, 1891, Mr. and Mrs. Spreckles, domiciliaries of California, owned shares of corporate stock as community property. On that date the amendment became effective, and thereafter the husband could not "make a gift of ... community property, or convey the same without a valuable consideration, unless the wife, in writing, consent thereto." ${ }^{42} \mathrm{Mr}$. Spreckles later gave the stock to one of his children without obtaining either the consent of his wife or a valuable consideration. In deciding a subsequent suit to recover the stock, the court disposed of the case by holding that the amendment did not apply to property acquired prior to its enactment.

Contrary to the supreme court's treatment of it in later cases, it has been established that the Spreckles decision did not adjudicate that, as a matter of due process, retroactive application of the amendment would work an unconstitutional disturbance of the husband's "vested" interest in the community property. ${ }^{43}$ That conclusion was stipulated by counsel and assumed by the court: the only contest in the case, and hence the only adjudication, concerned whether the husband had the entire vested interest in the community propery before the time of amendment. Once the court had decided that the husband was the owner of the community property and the wife had no more than an expectancy, the stipulation controlled ${ }^{44}$ and the case was at an end.

The cases following Spreckles that established the effect of other pre1927 legislation enlarging the wife's rights in the community property are of two types: (1) those deciding the retroactivity point; ${ }^{45}$ and (2) those

30 Ibid.

40116 Cal. 339, 48 Pac. 228 (1897).

41 Cal. Stat. 1891 ch. CCXX, at 425 (amending Car. Crv. Code $\$ 172$ ).

42 Ibid.

43 Authorities cited note 37 supra.

44 Spreckles v. Spreckles, 116 Cal. 339, 349, 48 Pac. 228, 231 (1897).

45 Arranged in chronological order according to the dates of the amendments held not retroactive, the cases are: Duncan v. Duncan, 6 Cal. App. 404, 92 Pac. 310 (1907) (1901 amendment to Civil Code $\$ 172$ preventing husband's sale, conveyance, or encumbrance of furniture and clothing without the wife's consent) ; Roberts v. Wehmeyer, 191 Cal. 601, 218 Pac. 22 (1923) (1917 enactment of Civil Code §172a preventing the husband's conveyance of community real property without his wife's consent); McKay v. Lauriston, 204 Cal. 557, 269 Pac. 519 (1928) (1923 amendment to Civil Code $\$ 1401$, now Probate Code $\$ 201$, giving the wife testamentary control over half the community property); Boyd v. Oser, 23 Cal.2d 613, 145 P.2d 312 (1944) 
deciding that, considered prospectively, the statute in question did not create a vested interest in the wife. ${ }^{46}$ Cases of the first type do not present the constitutional issue, since in thein, as in Spreckles, the energies of counsel were directed toward establishing a vested interest in the wife. Having failed in that pursuit, the argument for retroactivity collapsed. Nor do cases of the second type raise the issue, since in them, counsel were interested in the prospective creation of a vested interest in the wife. The further question whether such an interest could constitutionally liave been applied retroactively was not reached, because none of the cases lield that the pre1927 changes had created a vested interest in the wife. In 1927 the legislature expressly made the wife's interest in the community property equal to lier husband's, but he was allowed to retain his powers of management and control over the entire community estate, including his wife's newlycreated interest. ${ }^{47}$ Shortly thereafter the retroactivity question was raised, and it was thereupon decided that the enactment did not apply retroactively. ${ }^{48}$ The cases involving post-1927 amendments (applied to post1927 property) of course do not discuss the problem of the wife's vested interest; they merely decide, in a routine fashion, the retroactivity point. ${ }^{49}$ The only recent case discussing the constitutional point arose in the context of the out-of-state property statute, Probate Code section 201.5. ${ }^{50}$

The 1961 amendment, by virtue of its application to property acquired

(same) ; Henry v. Hibernia Sav. \& Loan Soc'y, 5 Cal. App. 2d 141, 42 P.2d 395 (1935) (1927 enactment of Civil Code $\$ 161 \mathrm{a}$, making the wife's interest in the community property equal to that of her husband, cf. Stewart v. Stewart, 204 Cal. 546, 554-55, 269 Pac. 439, 442-43 (1928)).

46 Spreckles v. Spreckles, 172 Cal. 775, 158 Pac. 537 (1916) (1891 amendment to Civil Code $\$ 172$, see note 45 supra) ; Stewart v. Stewart, 199 Cal. 318, 249 Pac. 197 (1926) (1917 enactment of Civil Code \$172a, see note 45 supra); Stewart v. Stewart, 204 Cal. 546, 269 Pac. 439 (1928) (second opinion, reiterating the prior holding to a recalcitrant trial court); Trinible v. Trimble, 219 Cal. 340, 26 P.2d 477 (1933) (1923 amendment to Civil Code $\$ 1401$, now Probate Code $\$ 201$, see note 45 supra).

47 Cal. Stat. 1927 ch. 265 , at 484.

48 Henry v. Hibernia Sav. \& Loan Soc'y, 5 Cal. App. 2d 141, 42 P.2d 395 (1935) ; cf. Stewart v. Stewart, 204 Cal. 546, 554-55, 269 Pac. 439, 442-43 (1928).

49 Jacquemart v. Jacquemart, 125 Cal. App. 2d 122, 269 P.2d 951 (1954) (1951 enactment of Civil Code $\$ 169.1$, making the earnings and accumulations of both spouses separate property after the entry of a separate maintenance decree); Ottinger v. Ottinger, $141 \mathrm{Cal}$. App. 2d . 220, 296 P.2d 347 (1956) (1955 amendment to Civil Code \$175, making the husband's earnings separate property during his wife's unjustified abandonment of him under certain conditions); cf. Ferguson v. Rogers, 168 Cal. App. 2d 486, 336 P.2d 234 (1959) (noting the express legislative intent for prospective application of Civil Code $\S 163.5$, enacted in 1957, making damages awarded in a civil action for personal imjuries separate property). Other new enactments that presumably will be given the same treatment in a proper case include that part of Civil Code $\S 171 c$, enacted in 1951, giving the wife management and control of her "commumity property money earnings"; and Civil Code $\$ 169.2$, enacted in 1959, making the husband's earnings and accumulations his separate property following the entry of an interlocutory decree of divorce.

50 Paley v. Bank of America, 159 Cal. App.2d 500, 324 P.2d 35 (1958). 
"heretofore or hereafter," will reopen in a proper case the question of the legislature's constitutional power to disturb vested property rights by retroactive legislation..$^{51}$ It seems important, therefore, to point out that the problems of the Spreckles and Thornton cases, so far as the due process clause is concerned, present the same issue. There is essentially no difference between retroactive application of a statute changing the respective powers of spouses over community property and application of community property concepts to common-law property. ${ }^{52}$ The parallel may be stated as follows, using Professor Currie's conflict-of-laws terminology: ${ }^{68}$ In the retroactivity case, although California had a legitimate interest in determining the relative property rights of the California spouses at the time they acquired property in California, no policy similar to that expressed in the subsequently-enacted amendment then existed. In the extra-state case, although California's community property policy was in effect at the time the property was acquired, California had no legitimate interest in applying that policy to the common-law spouses, so long as they and their property remained outside the state. Once the amendment was enacted or the common-law spouses and their property were within the state, however, the constitutional issue is the same, so that to the extent California may reasonably make the amendment retroactive, she may apply it to cases in which the property was acquired elsewhere. ${ }^{54}$

Before the enactment of Civil Code section 161a in 1927, the parallel was exact. That section is commonly spoken of as having given the wife a vested interest in the community property. Prior to 1927, the California husband was said to be the sole owner of the community property; his wife's

51 The legislative history is persuasive. After the decision in Estate of Frees, 187 Cal. 150, 201 Pac. 112 (1921), the legislature inserted into the statute the words "heretofore or hereafter." In Estate of Drishaus, 199 Cal. 369, 249 Pac. 515 (1926), the court treated these words as indicating a legislative intention to make the statute retroactive. See note 36 supra.

52 The same argument is made with relation to application of the Statute of Frauds, where the problem is one of impairment of the obligation of contract, in Currie \& Schreter, Unconstitutional Discrimination in the Conflict of Laws: Privileges and Immunities, 69 YaLE L.J. 1323,1334 (1960). The argument propounded there was accepted by the California Supreme Court in Bernkrant v. Fowler, 55 Cal. 2d 588, 595, 360 P.2d 906, 910, 12 Cal. Rptr. 266, 270, 49 CALrF. L. Rev. 962 (1961) (Traynor, J., writing for a unanimous court). See also Currie, The Verdict of Quiescent Years: Mr. Hill and the Conflict of Laws, 28 U. CHn. L. REv. 258, 289-94 (1961), where the point is developed in connection with the case of Clay v. Sun Ins. Office, Ltd., 363 U.S. 207 (1960).

58 E.g., Currie, Notes on Methods and Objectives in the Confict of Laws, 1959 Dure L.J. 171.

54 Currie \& Schreter, supra note 52, at 1334. Prior to the 1917 enactment of $\S 164$, California expressed no legislative policy about property acquired elsewhere and brought into the state. She therefore lacked a policy for, as well as an interest $\mathrm{m}$, persons owning that property. The 1917 enactment declared the state policy of applying to newcomers the pre-1917 concepts of community property law, as well as concepts subsequently adopted by the legislature. 
interest was said to be a mere expectancy. ${ }^{55}$ The same statements could be and were used to describe the respective interests of the spouses in commonlaw property. ${ }^{66}$ Thus, the 1891 amendment that gave the California wife a veto power over her husband's gifts of community property ${ }^{57}$ raises the same constitutional problem about previously-acquired community property that it raises when applied to common-law property acquired either before or after 1891 and brought to California after 1891 . It may be argued that the situation is different after 1927, since the California husband is no longer the sole owner of subsequently-acquired ${ }^{58}$ community property. According to this line of reasoning, giving the common-law wife community rights in common-law property would deprive her husband of substantial property rights, because the wife's rights in the property would be so greatly increased. It should not be concluded from the mere enactment of section 161a, however, that the California wife's imterests in community property are substantially more extensive than those of the common-law wife in equivalently-acquired property.

Whatever might have been thought at the tinie, ${ }^{\text {s9 }}$ today it is clear that the "vested" right of the California wife has been accorded her only by the tax cases. ${ }^{80}$ The 1927 amendment placed the wife's newly created interest under her husband's power of management and control. Because the community property is thought to be indivisible except upon death, divorce, or voluntary arrangement of the spouses ${ }^{61}$ the wife's creditors were unable to withdraw her interest from her husband's control to satisfy her tort liabilities. ${ }^{62}$ Nor were her tort creditors permitted to apply both spouses' interests in the community property to their debts, since the husband was not liable for his wife's torts. ${ }^{63}$ The husband's exclusive powers of management and control, however, meant that his creditors could subject both his inter-

65 See Spreckles v. Spreckles, 116 Cal. 339, 344-48, 48 Pac. 228, 230-31 (1897) (reviewing the early cases) ; Stewart v. Stewart, 199 Cal. 318, 321-35, 249 Pac. 197, 199-206 (1926) (same); Roberts v. Wehmeyer, 191 Cal. 601, 607-10, 218 Pac. 22, 24-25 (1923) (reviewing the Spanish law).

58 See MARSH 45-46 (explaining the "vested rights" terminology, but declining to use it himself as not being meaningful); see also MaRSH 11-67.

57 See text at notes $41-42$ supra.

Es See note 48 supra.

60 See Kirkwood, The Ownership of Community Property in California, 7 So. CaL. L. Rev. 1, 11-13 (1933) ; Simmons, The Interest of a Wife in California Community Property, 22 Cacr.

L. REv. 404, 417-18 (1934).

60 Marsh, "California Family Law"-A Review, 42 CaLr. L. Rev. 368, 375 (1954); see MARSH 48-49; of. 1 ARMSTRONg 588-89.

61 Britton v. Hammell, 4 Cal. 2d 690, 52 Pac. 221 (1935).

62 Smedberg v. Bevilockway, 7 Cal. App. 2d 578, 46 P.2d 820 (1935).

63 McClain v. Tufts, 83 Cal. App. 2d 140, 187 P.2d 818 (1947). There is no decision of the Cahifornia Supreme Court on this point. 
est and hers to liability for his torts. ${ }^{64}$ By parity of reasoning, the interest of both spouses in the wife's community property money earnings under her managment and control since 1951 should be liable for her torts, ${ }^{65}$ but no case has yet so held. Her share of the community property, ${ }^{60}$ except for her earnings, ${ }^{67}$ if they can be identified, ${ }^{08}$ is subject to her husband's contract debts during his lifetime and comes to hes: upon his death only after the debts of his estate are paid. ${ }^{69}$ In theory, at least, she still takes her share by succession from her husband, and is thus in privity with his estate for the purpose of deciding questions relating to the probate court's jurisdiction. ${ }^{70}$ Since her interest remains under her husband's management and control, the pre-1927 doctrine that the husband's unauthorized gifts of the community personal ${ }^{71}$ and real ${ }^{72}$ property made in violation of Civil Code sections 172 and $172 \mathrm{a}$ are not void but voidable at the wife's election has not been rejected, even though post-1927 property is involved. ${ }^{73}$ A recent

64 Grolemund v. Cafferata, 17 Cal.2d 679, 111 P.2d 641 (1941). Neither will the entire community interest, as distinguished from the wife's "one-half interest" therein, be subjected to liability for her torts so long as it remains under the husband's management and control. McClain v. Tufts, 83 Cal. App. 2d 140, 187 P.2d 818 (1947).

05 1 ARMSTrONG 706.

66 Spreckels v. Spreckles, 116 Cal. 339, 343, 48 Pac. 228, 229 (1897) (dictunr); Grolemund v. Cafferata, 17 Cal. 2d 679, 111 P.2d 641 (1941) (dictum). When the husband uses community funds under his management and control to improve his separate real property, the community acquires a proportionate right of reimbursement. Smith v. Smith, 12 Cal. 216 (1859) ; Provost v. Provost, 102 Cal. App. 775, 283 Pac. 842 (1929). The rationale of these cases applies whenever the husband uses commurity funds to pay debts incurred in the management of his separate estate. 1 ARMSTRONG 703.

67 Cat. Crv. Code § 168; Street v. Bertolone, 193 Cal. 751, 226 Pac. 913 (1924).

68 Street v. Bertolone, supra note 67. Before the wife's earnings were removed froin her husband's control and placed under her control in 1951, it was held that when the wife's earnings have been invested by the husband in other community property, the exemption is lost, even though the proportionate contribution of the wife's earnings to the new asset could be established and even though the wife could not have prevented the investment. Pfunder v. Goodwin, 83 Cal. App. 551, 257 Pac. 119 (1927); see 1 Armstrong 695.

69 Cat. Prob. Code $\$ 202$; Estate of Coffee, 19 Cal. 2d 248, 120 P.2d 661 (1941).

70 Colden v. Costello, 50 Cal. App. 2d 363, 122 P.2d 959 (1942); see 1 ARMsTrove 734-35. As to pre-1927 property, see In re Burdick, 112 Cal. 387, 44 Pac. 734 (1896).

71 Spreckles v. Spreckles, 172 Cal. 775, 158 Pac. 537 (1916). But cf. Fields v. Michael, 91 Cal. App. 2d 443, 449, 205 P.2d 402, 406 (1949), reserving the question whether $\S 161$ a has enlarged the wife's rights when her husband makes gifts of community personal property. The husband's encumbrance of household furniture without his wife's consent has been held void. Dynan v. Gallinatti, 87 Cal. App. 2d 553, 197 P.2d 391 (1948).

72 Dargie v. Patterson, 176 Cal. 714, 169 Pac. 360 (1917); cf. Medeiros v. Cotta, $130 \mathrm{Cal}$. App. 740, 279 P.2d 814 (1955) (relying on pre-1927 cases in a case involving post-1927 land).

73 In Horton v. Horton, 115 Cal. App. 2d 360, 252 P.2d 397 (1953), plaintiffs, husband and wife, brought a quiet title action to recover community property given away by the husband. Although prior cases had limited such actions to equitable proceedings to cancel the deed or to declare a constructive trust, the court permitted the suit on the following theory:

[U]nder these sections [Civil Code $\$ \$ 161 \mathrm{a}$ and 172a] the wife has a vested legal interest in community real property and . . . an instrument of conveyance executed 
case has, however, permitted a deceased incompetent wife's personal representative to set aside her husband's unauthorized gifts of community personal property on the ground that section 161a created a property right in the wife for the invasion of which an action may be maintained after her death. ${ }^{74}$ For certain purposes, the husband is held to the standards of a fiduciary while managing his wife's share of the community property, ${ }^{75}$ but there is no indication that this duty extends only to post-1927 property. ${ }^{76}$ It seems clear from these examples that in testing the constitutionality of either the retroactive or extra-state application of section 161a, the actual incidents of control it accords the wife should be carefully evaluated. ${ }^{77}$ The inquiry merely begins, rather than ends, with the statement that the amendment gives the wife a vested interest in community property. ${ }^{78}$

If the propositions are accepted that retroactivity and reclassification present the same constitutional questions under the due process clause, and that these problems are the same before and after 1927, then the issue was squarely raised prior to its appearance in the Thornton case. The 1917 amendment to section $164^{79}$ did not expressly state the legislative intention, if such there was, that the amendment was to apply retroactively to property brought to Califorma prior to its enactment. Indeed, the supreme court twice found such intention lacking. ${ }^{80}$ In 1923, however, the legislature clearly indicated its intention by adding the words "heretofore or hereafter" to its prior enactment. ${ }^{81}$ Whether that intention could be realized

by the husband alone only serves to convey the legal title to the property if the wife fails to commence an action to avoid it within one year after the date of its recordation. The deed executed by the husband merely serves as a cloud upon the title of the wife and does not ripen into an effective conveyance unless the wife fails to take steps to avoid it within the period specified in said section 172a.

Id. at 364,252 P.2d at 400 . The court also sustained plaintiff's recovery on the independent ground that since defendants and the court understood that plaintiffs were attacking the deeds, reversal on the quiet title form of the pleadings would constitute a miscarriage of justice. Id. at 365, 252 P.2d at 400-01. For criticism, see 1 Armstrong 182-83 (1961 Cum. Supp.). See also Estate of Kelley, 122 Cal. App. 2d 42, 264 P.2d 210 (1953) (criticized in Marsh, "California Family Law"-A Revieve, 42 CALIF. L. Rev. 368, 374-75 (1954)); Cooke v. Cooke, 65 Cal. App. 2d 260, 150 P.2d 514 (1944).

74 Harris v. Harris, 57 A.C. 403,369 P.2d 481, 19 Cal. Rptr. 510 (1962).

75 Vai v. Bank of America Nat'l Trust \& Sav. Ass'n, 56 A.C. 327, 364 P.2d 247, 15 Cal. Rptr. 71 (1961), 50 CATIF. L. REV. 131 (1962).

76 The Vai case, supra note 75 , involved a community property winery acquired in 1912.

The court made no distinction between pre- and post-1927 property.

77 MARSH $48-50$.

78 Mars 45; Marsh, "California Family Law"-A Review, 42 CaLIF. L. Rev. 368, 374-75 (1954). But see authorities cited note 59 supra.

79 See note 36 supra.

80 Estate of Frees, 187 Cal. 150, 201 Pac. 112 (1921) ; Estate of Arms, 186 Cal. 554, 199

Pac. 1053 (1921).

81 See note 36 supra. 
constitutionally was first raised in Estate of Drishaus, ${ }^{82}$ decided eight years before Thornton. The Drishaus case would have lent itself admirably to a discussion of the argument here presented. It involved personal property brought to California from a common-law state in 1916, thus raising both the question of retroactivity and the question of extra-state application of the pre-1917 community property concepts. By an unhappy coincidence, the Drishaus case was handed down precisely two weeks after the same court had unanimously reiterated the Spreckles doctrine in passing on the 1917 amendment requiring the wife's consent to the sale of community realty ${ }^{83}$ The Drishaus conclusion was inevitable; citing Spreckles and its most recent offspring, the court announced its decision in one sentence:

The effect of these earlier and later decisions of this court cannot be held to be other than that of deciding that the vested interest which the decedent in the instant case had in the personal property brought by him to this state as his separate property, and since then up to the time of his death held and owned by him as his separate property and estate, was unaffected by the foregoing amendments to the Civil Code, and that at the time of the death of said decedent the whole of said property was his separate property and estate ....$^{84}$

The decision appears to have been based solely on the retroactivity point, which in turn was based on the Spreckles line of cases ${ }^{85}$ there was no discussion of the constitutional issue. Thus, Estate of Thornton remains the only case decided by the California Supreme Court to adjudicate the constitutional question. ${ }^{86}$

The basis of the Thornton decision on the due process question is far from clear. The court's reasoning on this point occupied two short sentences: "Again, to take the property of $A$ and transfer it to $B$ because of his citizenship and domicile, is also to take his property without due process of law. This is true regardless of the place of acquisition or the state of his residence." ${ }^{87}$ The court apparently disregarded the fact that the $A$ and $B$ involved in the statute must necessarily be husband and wife. Nor did the court consider sigmificant the legislative purpose of protecting $B$, the wife, from losing valuable rights when she and her husband moved to California. Contrary to the court's implication, the statute contained no indication that $B$ was to receive $A$ 's property simply because $A$ had become a California domiciliary. Rather, by regulating the marital relationship, the legislature

82199 Cal. 369, 249 Pac. 515 (1926).

83199 Cal. 318, 249 Pac. 197 (Sept. 2, 1926). The Drishaus case was decided September 16, 1926.

84199 Cal. 369, 373, 249 Pac. 515, 516 (1926).

85 See notes 45,46 supra.

${ }^{86}$ See Armstrong, "Prospective" Application of Changes in Community Property Control -Rule of Property or Constitutional Necessity?, 33 CarrF. L. Rev. 476, 497 (1945).

87 Estate of Thornton, I Cal. 2d 1, 5, 33 P.2d 1, 3 (1934). 
sought to substitute community property rights for the common-law rights that $B$ lost in changing domiciles. ${ }^{88} \mathrm{It}$ is undeniable that $B$ 's newly acquired rights would have limited $A$ 's control of the property more severely, in some respects, than the rights she had lost, but that consideration merely raises the due process issue without answering it. I shall not discuss the due process arguments that sustain retroactive application of amendnients changing the incidents of community property control. That job has already been done by Professor Barbara Armstrong ${ }^{89}$ and others..$^{90}$ It nuay be useful, however, to suggest a possible explanation for the Thornton court's cryptic statement of its due process holding.

In its original opinion in Estate of Thornton, ${ }^{91}$ the court advanced two postulates to support its holding that the reclassification statute was constitutional. The first was drawn exclusively from a law review comment dealing primarily with Estate of Drishaus; ${ }^{92}$ the second was based upon use of the police power to regulate the marriage relation and its incidental property rights. The burden of the first argument was that the statute did not deprive Mr. Thornton of a vested property right without due process of law because at the time he entered California, he had no vested property rights. ${ }^{93}$ The argument was expressly grounded on two notions: first, that the due process clause applies only within the territorial boundaries of each state to property interests created by the laws of that state in persons there domiciled; and second, that no state has power to invest its domiciliaries with property interests that must be recognized within the territorial boundaries of any other state, at least when contrary to a "positive statute" of the other state. ${ }^{04}$ When Mr. Thornton lived in Montana, its laws created certain rights in him against the world in general and his wife in particular. So long as he and the property remained in Montana, the law of California could not affect them. These rights terminated, however, at the Montana border. As a result, $\mathrm{Mr}$. Thornton entered California with tangible items in his possession, but without any law to define the respective interests in those items.

88 See text at notes 6-9, 17-24 supra.

89 See note 86 supra.

90 Comment, Community and Separate Property: Constitutionality of Legislation Decreasing Husband's Power of Control over Property Already Acquired, 27 CaLIE. L. REv. 49 (1938). See generally Smith, Retroactive Laws and Vested Rights (pts. 1-2), 5 TEXas L. REv. 231 (1927), 6 TeXas L. REv. 409 (1928); Slawson, Constitutional and Legislative Considerations in Retroactive Lazmaking, 48 CALrF. L. REv. 216 (1960).

91 In re Thornton's Estate, 19 P.2d 778 (1933).

92 Comment, Conflict of Laws: Matrimonial Property: Effect on Movables of Change of Domicile from a Common Law State to a Community Property State, 15 CALIE. L. REv. 399, 407 n.36 (1927).

03 In re Thornton's Estate, 19 P.2d 778, 783 (1933).

04 Ibid. The cautious reference to "positive" statutes apparently relates to problems of extending full faith and credit to statutes of the common-law state, as distinguished from judgments, creating the property interests. 
California immediately supplied as the governing law its "positive statute," Civil Code section $164 . .^{95}$ The court's adoption of this argument as one basis for its holding apparently had a devastating effect on counsel for Mr. Thornton's estate. In his brief on rehearing, he was reduced to insisting that "as far as the Constitution of the United States is concerned, a vested property right is a vested property right." 06

There are, however, other avenues by which to approach this combination of constitutional law and conflict of laws theory. The court's argument is a logical application of Story's territorial theory that the laws of each nation possess an exclusive sovereignty and jurisdiction within their respective territories. ${ }^{97}$ The corollary of the theory is said to be that the laws of no state or nation can directly affect or bind property outside its territory or persons not present therein. ${ }^{98}$ Taken together, the two propositions are said to mean that whatever force the laws of one country have in another depends upon the laws of the second country. ${ }^{90}$ As the law review writer who commented on the Drishaus case correctly understood, the territorial theory is completely self-sufficient and independent of the later notion of vested rights advocated by Beale. ${ }^{100}$ Adherents of the vested rights idea build upon the concept of territorialism by developing from it their specialized theory of legislative jurisdiction, which in turn depends on a super-law

$95 \mathrm{Ibid}$. One may wonder what law or laws defined the property rights of the husband during his trip from Montana to California. It may be suggested tbat, according to the established doctrine, the law of Montana, as the law of the prior domicile, would continue to apply until the law of California was established as that of the superseding domicile of choice. See REsTATEMENT (SECOND), Conflict of Laws $\$$ 15, 23 (Tent. Draft No. 2, 1954). There is no indication that Cahifornia was Thornton's domicile of origin. Even if it had been, there is authority to the effect that American law will not nake an exception from the general rule in the case of a return to the domicile of origin. Estate of Jones, 192 Iowa 78, 182 N.W. 227 (1921).

96 Respondent's Petition for Rehearing, p. 28, Estate of Thornton, 1 Cal.2d 1, 33 P.2d 1 (1934).

97 Story, Comgmentaries on the Conflict of Laws $\$ 18$ (1834) [hereinafter cited as STORY].

08 STORY $\$ 20$.

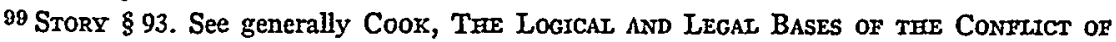
LAws 48-70 (1949) ; EHRENZWEIG, CoNflict of LAwS, PART I \$\$ 2-5 (1959) [hereinafter cited as EHREnzweIG]; Cavers, Two "Local Law" Theories, 63 HARv. L. Rev. 822 (1950); Cheatham, American Theories of Conflict of Laws: Their Role and Utility, 58 HARv. L. REv. 361, 373-78 (1945); Currie, Notes on Methods and Objectives in the Conflict of Laws, 1959 DUKE L.J. 171.

1003 Beare, The Confutct of Laws 1967-69 (1935) [hereinafter cited as Beate] ; Yntema, The Historic Bases of Private International Law, 2 AM. J. CoMp. L. 297 (1953), reprintcd in Selected Readngss on Conflict of Laws 30 (1956). See also Stimson, Which Law Should Govern?, 24 VA. L. Rev. 748, 755, 762 (1938). But see Niboyet, Territoriality and Universal Recognition of Rules of Conflict of Laws, 65 HARv. L. REv. 582, 592 (1952), arguing that the principle of territoriality must be complemented by a notion suspiciously similar to that of the vested-rights adherents' legislative jurisdiction, although the author recognizes that the suggested principle is "im a sense, the converse of the principle of territoriahity . ..." The conl- 
capable of defining such jurisdiction. ${ }^{101}$ Thus, it is perfectly consistent for a territorialist to say that the due process clause operates only within the territorial boundaries of each state and does not require the recognition of rights created in one state by another state. Such recognition, however, is compelled in the United States, insofar as it is compelled at all, by the only "super-law" that actually assigns "legislative jurisdiction" with its accompanying doctrine of "vested rights": 102 the federal constitution, particularly the full faith and credit clause. And at least as far as full faith and credit to statutes is concerned, the United States Suprenie Court has reiterated that "the Full Faith and Credit Clause does not require a State to substitute for its own statute, applicable to persons and events within it, the statute of another State reflecting a conflicting and opposed policy."103 The important phrase is "reflecting a conflicting and opposed policy." In Thornton, the only difference in policy between California and Montana, and hence the only potential conflict of laws problem that might liave been resolved by the full faith and credit clause, ${ }^{104}$ related to the changes in the husband's powers of management and control of the property acquired in Montana and brought to California. Since the general concept of private property has been adopted by all states, even if $\mathrm{Mr}$. Thornton is said to have lost his Montana-created property rights upon moving, he would immediately reacquire in California substantially all of the powers and responsibilities that unark a definition of private property common to both states. The question whether California could constitutionally abolish the system of private ownership of property is not involved. ${ }^{105}$ But the court's state-

plementary notion is that "when a right is governed by the law of a foreign country because the facts involved occurred there, this authority or competence has to be accepted as a matter of principle by other countries, even if the law involved is merely territorial; the only reservation which remains is that of public policy."

1013 BeALe 1974; EHRENZWEIg \$ 4; Cavers, Two "Local Law" Theories, 63 Harv. I. Rev. 822, 826-31 (1950).

102 EHRENZWETG $\S 4$, at 10.

103 Carroll v. Lanza, 349 U.S. 408, 412 (1955). The position was originally stated by Mr. Justice Stone. See Pacific Employers Ins. Co. v. Industrial Acc. Comm'n, 306 U.S. 493, 502 (1939); Alaska Packers Ass'n v. Industrial Acc. Comm'n, 294 U.S. 532, 547-48 (1935). See generally EHRENzwerg $\$ \S 9,38$; Currie, The Constitution and the Choice of Law: Govermnental Interests and the Judicial Function, 26 U. CHI. L. REv. 9 (1958) ; Jackson, Full Faith and Credit-The Lawyer's Clause of the Constitution, 45 CoLom. L. Rev. 1 (1945); Nadelmann, Full Faith and Credit to Judgments and Public Acts, 56 Micr. L. Rev. 33 (1957).

104 The potential conflict will become a true conflict of laws problem only if California and Montana have a conflict of interests in the case as well as a conflict of policies on the statute books. See Currie, Married Women's Contracts: A Stady in Conflict of Laws Method, 25 U. CEI. L. REv. 227, 251 passim (1958).

105 See generally Coker, American Traditions Concerning Property and Liberty, 30 Axr. Por. Scr. Rev. 1 (1936) ; Kales, "Due Process," The Inarticulate Major Premise and the Adamson Act, 26 YaLe L.J. 519 (1917); Pound, The New Feudal System, 19 KY. L.J. 1 (1930). All are reprinted in 2 SEIECTEd Essays on ConstituTIONAL LAW (1938). 
ment that due process forbids taking $A$ 's property and giving it to $B$ purely because of a change in domicile implies that California's border officials stood ready to take $A$ 's automobile acquired in Montana and deliver it to some third person unknown to $A$, to be held as that person's private property, nevermore useful or beneficial to $A{ }^{100}$ The statement is, in short, too broad to be helpful in deciding the narrower issue raised in the Thornton case.

The analytical foundations for these or similar arguments delimiting the boundaries of the due process argument of the first Thornton opinion had not at that time been published. ${ }^{107}$ The reaction of counsel on both sides to the argument was perhaps typical of busy practitioners faced with a novel theory. Those in whose favor the argument operated did not know how to capitalize on their good fortune; those on the other side, uncertain low to answer it, contented themselves by frightening the court with a "parade of horribles" attendant upon its retention as law. Confronted with this concentrated attack the court retreated and rendered its cryptic pronouncement on the due process issue. Lost in the melee was the court's second and infinitely sounder constitutional argument based upon the use of the police power to control and regulate the marriage relation and its incidental property rights. ${ }^{108}$ The court did not even bother to dispose of this aspect of its prior opinion. Thus the only adjudication by the California Supreme Court ${ }^{109}$ of the due process question may represent the court's hasty withdrawal from an interpretation of the clause that it was unable to sustain.

There is yet another reason for the court's relegation of the due process issue to comparative obscurity in the second Thornton opinion: its newly conceived argument expressly based on the privileges and immunities clause of the fourteenth amendment. The argument is that because California does not apply retroactively amendments changing the relative interests of California spouses in community property ${ }^{110}$ and a fortiori the California husband's separate property, failure to extend the same protection to the

106 Indeed, the hiterature commonly himits the " $A$ and $B$ " example to a law "which takes property which belongs to $A$ and gives it to $B$, without regard to any prior relations between the parties." Smith, Retroactive Laws and Vested Rights, 5 Texas L. REv. 231, 232 (1927) (emphasis added); see authorities cited note 105 supra.

107 Authorities cited note 99 supra.

108 In re Thornton's Estate, 19 P.2d 778, 784 (1933) ; see Armstrong, "Prospective" Application of Changes in Community Property Control-Rule of Property or Constitutional Necessity, 33 CAIIF, L. REv. 476 (1945).

109 The constitutional question was raised in connection with the pre-1957 version of Probate Code $\$ 201$ and decided by rehance on Thornton in Paley v. Bank of America, 159 Cal. App. 2d 500, 324 P.2d 35 (1958).

110 See notes 44,45 supra. 
common-law husband's powers in his separate property would abridge the latter's privileges and immunities as a citizen. ${ }^{111}$

The argument as stated is either unnecessary to the decision or based on the wrong constitutional provision. The privileges and immunities that the fourteenth amendment protects from state abridgment are those created by federal law. ${ }^{112}$ Before the clause can be used, therefore, some other provision of federal law must be relied upon to create the privilge or immunity in question. ${ }^{113}$ Two possibilities are suggested by the facts of the Thornton case: (1) the fourteenth amendment immunity from state deprivation of one's property without due process of law; and (2) the privilege, suggested by counsel, ${ }^{114}$ of residing in any state and becoming a citizen thereof on conditions of substantial equality with other citizens of the state. While it is correct to say that the due process immunity is one of national citizenship protected from abridgment by the privileges and immunities clause, to estabhish the abridgment one nuust first establish the deprivation. ${ }^{115}$ If the due process clause permits reclassification in community terms of commonlaw property brought to Cahfornia by new domiciliaries, then the privileges and immunities clause is not apphicable, for no right created by the federal government has been abridged. If, on the other hand, the reclassification is prohibited by the due process clause, then the privileges and immunities clause is applicable. But its use adds nothing to the subsisting unconstitutionality that results under the due process clause. The same analysis seems applicable to the asserted privilege of residing in the state on terms of equality with other citizens of the state. ${ }^{116}$ Insofar as the argument cannot be maintained under the privileges and immunities clause of article IV, to be discussed in a noment, it appears to rest on the due process clause. If California can change local property rights retroactively, then she can similarly change the property rights of newconiers whose national rights are no higher than those of local citizens in this regard.

Even if the privileges and immunities clause of the fourteenth amendment lends no strength to the Thornton holding, the quite different privi-

111 Estate of Thornton, 1 Cal. 2d 1, 5, 33 P.2d 1, 3 (1934).

112 The Slaughter-House Cases, 83 U.S. (16 Wall.) 36 (1872); McGovney, Privileges or Immunities Clause, Fourteenth Amendment, 4 IowA L. Butr. 219 (1918), reprinted in 2 Sexected Essays on Constitutionat Law 402 (1938).

118 McGovney, supra note 112, at 243-44, 2 Selected Essays on Constrtutionat Law 402, 423-24 (1938).

114 Respondent's Petition for a Rehearing, pp. 13-19, In re Thornton's Estate, 19 P.2d 778 (1933). See also Paley v. Bank of America, 159 Cal. App. 2d 500, 508-09, 324 P.2d 35, 41 (1958). 115 McGovney, supra note 112, at 242-43, 2 Selected Essays on Constitutionax LAw 402,423 (1938).

116 See Bowman, The United States Citizen's Privilege of State Residence, 10 B.UI. REv. 459 (1930), reprinted in 2 Selected Essays on Constirutionax Law 425 (1938). 
leges and immunities clause of article IV of the Constitution, which deals with rights created by state laws, may independently sustain the court's decision. The Spreckles doctrine forbidding retroactivity may be established, for purposes of the latter clause, either by the due process clause of the state constitution or by state property law. If the doctrine is established by interpretation of the state constitution, that interpretation may be overruled by a subsequent decision of the state supreme court or terminated by an amendment, for privileges and immunities granted by the state may be withdrawn by it. ${ }^{117}$ If the doctrine is inerely a matter of state property law, then it may be safely disregarded by the legislature in new enactments, including the 1961 enactment here under discussion. ${ }^{118}$ In either case, however, the article IV clause requires that privileges and immunities created by California law for the benefit of local citizens be extended to citizens of other states who move to California unless a classification excluding the non-citizen can be sustained as reasonable. ${ }^{119}$ If one assumes that the immunity granted to the California husband is substantially the same as that sought to be withheld from the common-law husband, there is no apparent justification for the classification in light of the United States Supreme Court's prior treatment of the clause. ${ }^{120}$ And since this does not appear to be a case in which the fact of citizenship itself would sustain the discrimination, presumably the equal protection clause would compel the same result for aliens. ${ }^{121}$

Even this limited argument, sustaining the Thornton result as a matter of state law only so long as Spreckles endures, is subject to one last qualification. The Thornton court, ${ }^{122}$ like earlier courts, ${ }^{123}$ equated the civil-law concept of separate property found in community property states with the common-law concept of separate property and assumed that the husband holds similar powers in the two species of property. Professor Marsh has established, however, that the two types of property bear no close relation to each other. Indeed, based on his detailed analysis of statutes and judicial decisions, he offers the following "qualified generalization":

The wife's interest in the so-called statutory "separate" property of the husband in a majority of the common-law states is afforded a protection

117 See McGovney, supra note 112, at 229-30, 2 Selected Essays on Constitutional Law 402,411 (1938).

118 See Traynor, $J_{\text {, }}$ concurring in Boyd v. Oser, 23 Cal. 2d 613, 623, 145 P.2d 312, 318 (1944).

119 See Currie \& Schreter, Unconstitutional Discrimination in the Conflict of Lawes: Privileges and Immunities, 69 YaLE L.J. 1323 (1960).

120 Id. at $1335-49$.

121 Id. at 1349 and n.101.

122 Estate of Thornton, 1 Cal. 2d 1, 3-4, 33 P.2d 1, 2 (1934). See text at notes 110-11 supra, for an amplification of this point.

123 See notes 12,16 supra. 
nearly equal to that given her interest in the community property acquired by the husband in the majority of community property jurisdictions. ${ }^{124}$

The husband ${ }^{125}$ should not be permitted, therefore, to rely upon the incorrect assimilation of common-law separate property to civil-law separate property in order to establish the applicability of the Spreckles doctrine and hence the privileges and immunities clause of article IV. In each case, he should be required to show that the wife's claim against his common-law property will in fact substantially change his powers as they existed under the law that applied at the time of acquisition. For example, if the wife complains that by making a gift her husband has attempted to extinguish her interests in an item of personal property, and if the item was acquired through the use of the husband's salary in one of the thirty-three common-law jurisdictions that prohibit such gifts when they are in fraud of the wife's rights, ${ }^{126}$ she should be permitted to establish that fact. The husband should then be required to answer by establishing, if he can, his freedom from fraud. He should not be permitted to avoid his wife's claim simply by classifying the property as his separate property of which he may freely make gifts. ${ }^{127}$ But if the wife attempts to set aside her husband's transfer without proving that it was in fraud of her rights, she should be limited by the Spreckles doctrine against retroactive application of the amendment prohibiting his unilateral gifts of commumity property. Prior to the 1891 amendment prohibiting the husband's gifts of community property without his wife's consent, ${ }^{128}$ the law of California allowed the wife to set aside such gifts only if they were in fraud of her rights. ${ }^{128}$ Since that amendment was held not applicable to gifts of pre-1891 community property, ${ }^{130}$ presumably the common-law husband merits a holding under the privileges and immumities clause that the amendment does not apply to property acquired by him in a common-law state at any time.

So long as the Spreckles doctrine remains embedded in California law, I do not see any effective answer to the qualified and limited basis for sustaining the Thornton result found in the privileges and immunities clause of article IV. If it is recoguized, however, that the federal constitution contains no obstacle to the abolition of the Spreckles doctrine, then there is equally no obstacle to the destruction of the Thornton result. These two

124 MarSH 45 . See generally MARSH 27-50.

125 The same point will apply to the wife if she is the acquiring spouse.

126 MARSH 37 n.101.

127 MARSE 37.

128 See text at notes $41-44$ supra.

129 Smith v. Smith, 12 Cal. 216 (1859). The doctrine was reiterated in a dictum in Stewart v. Stewart, 199 Cal. 318, 342-43, 249 P.2d 197 (1926) ("she has ... rights therein which have been always safeguarded against the fraudulent or inconsiderate acts of her husband . ..."). 130 Spreckles v. Spreckles, 116 Cal. 139, 48 Pac. 228 (1897). 
impediments to the reform of community property law in California may be ended simultaneously in a proper case. . $^{131}$

The question remains whether California has an interest in applying the commumity property system to property brought to that state by new domiciliaries. It may be urged that while California's interest in regulating the property relations of the spouses attaches to them when they arrive, that interest extends only to property subsequently acquired by them. The objection is seemingly buttresed by Currie's nusistence on assessing a state's policies and interests as of the tine the relevant transaction occurs. ${ }^{132}$ Enumeration of Cahfornia's interests in the application of her policy to property brought there by new domiciliaries, however, is not completed by the mention of her obvious governmental concern for those domiciliaries. An independent interest arises from the difficulty of administering fifty systems of marital property law in one state. In a study conducted under the direction of Professor Marsh and submitted to the California Law Revision Commission, the point is made that application of California's often irrational community property laws to common-law spouses is questionable as a matter of policy. ${ }^{1.33}$ Yet the penetrating critical insights forming the basis for this position are directed toward the existing community property laws themselves. How much more confusing than attempting to apply these rules to common-law spouses would the situation be if California had to sustain the cominon-law rules side by side with the community property rules? It was precisely this difficulty of coordination that impelled the 1917 amendment to Civil Code section 164. If California has the constitutional power to apply her cominunity system across the board to new domiciliaries, and I beheve she does, that should be done. Efforts to reform the irrational aspects of the system can then be directed at the source of the difficulty.

\section{II}

\section{"QUASI-COMMUNITY PROPERTY": THE 1961 ENACTMENT}

In the first section of this Article, the discussion was based on the assumption that the soundness of the Thornton decision should first be tested with a like case involving a married couple moving from a common-law

131 Because it has become a rule of property in California, the Spreckles case should be overruled only prospectively. See Traynor, J., concurring in Boyd v. Oser, 23 Cal. 2d 613, 623, 145 P.2d 312, 318 (1944); Armstrong, "Prospective"Application of Changes in Community Property Control-Rule of Property or Constitutional Necessity, 33 CALIr. L. REv. 476, 504-05 (1945); Traynor, La Rude Vita, La Dolce Giustizia; Or Hard Cases Can Make Good Law, 29 U. CEI. L. REv. 223, 232 (1962).

132 Currie, The Verdict of Quiescent Years: Mr. Hill and the Confict of Laws, $28 \mathrm{U}$. Crrr. L. REv. 258, 289-94 (1961), stating, however, that if a statute can be applied retroactively, then it can be applied to new domiciliaries.

133 LAW CoMme's Study at I-23, I-26. 
state to California, becoming domiciled in that state, and bringing property with them that is reclassified according to community concepts upon arrival. The 1961 enactment, however, is not limited to domiciliaries. ${ }^{134}$ Nor does it attempt to reclassify the property immediately. Indeed, the only property entirely reclassified is that of persons whose marriage is suspended by separate maintenance or dissolved by divorce. The statute does not specify whether the reclassification occurs at the time the cause of action for divorce or separate maintenance arises, at the time suit is filed, or at the time of determining the actual property division. The most appropriate moment appears to be the time suit is filed, since determination of when the action arose would be difficult, and postponenient to the time of actual division would place too great a risk on the non-acquiring spouse. Moreover, if the classification occurs when suit is filed, the non-acquiring spouse would have available remedies designed to preserve the property from destruction by the other spouse. ${ }^{135}$ If the spouses continue to live together as nuan and wife while they are domiciled in California, the new enactment will not affect them until death, unless they establish a marital homestead on the quasicommunity property. The statute literally applies to personal property wherever situated, although it eschews any attempt to regulate real property not located in California. Problems raised by the selectivity of the statute and its failure to specify the persons to whom it applies will be considered in the following pages.

It may be objected at the outset that the original pre-1917 version of Civil Code section $164^{136}$ contained no express limitation to domiciliaries, yet the courts uniformly imported such a himitation. That is certainly true. Indeed, the point was made in Estate of Frees, ${ }^{137}$ one of the pre-Thornton cases discussing the 1917 aniendment:

notwithstanding that the definition of community property has in terms included all property acquired by the husband or wife after marriage, other than that acquired by gift, bequest, devise, or descent, it has uniformly been held that property acquired in other states by persons domiciled therein and subsequently brought to California by them at the time of establishing residence in this state, retained the status that it had in the state where it was acquired, regardless of our definition of community property. ${ }^{138}$

The argument was, however, answered in the first Thornton opinion; the early interpretation was drawn from the "general principles" of conflict of laws and based on the notion of comity. The 1917 amendment repudiated

134 See note 30 supra.

135 See generally Rosenthal v. Rosenthal, 197 A.C.A. 311, 334-38, 17 Cal. Rptr. 186, 201-03 (1961).

136 Civil Code $\S 164$, in combination with $\$ \S 162$ and 163, defines community property.

137187 Cal. 150, 201 Pac. 112 (1921).

138 Id. at 154, 201 Pac. at 113. 
the idea of comity as far as marital property was concerned and established California's policy of applying the community property system to property acquired elsewhere. In passing upon the amendnent's validity, therefore, a California court could not properly disregard its specific terms by applying a choice of law rule pointing to the place of acquisition. The problem is "solely a constitutional question and does not involve any question of comity or of conflict of laws." 139

That answer remaims accurate for the 1961 enactment. Unless we are to remain bound by the notion of territorialism, ${ }^{140}$ we cannot automatically limit the enactnent to domiciliaries. We must instead isolate the cases that may raise problenus if the courts attenipt to apply the enactment literally. The method of approach will be to assume that the legislatively declared policy is boundless and to inquire whether California has an interest in applying that pohicy to each problem case. Each case will thus be tested according to the considerations set forth by Professor Brainerd Currie for ascertaining the constitutional limits placed on a state court's freedom to apply its own law to a case involving foreign elenents. ${ }^{141}$

Problems raised by the legislative failure to limit the concept of quasiconimunity property to property owned by persons who have become California domiciliaries are not solved by the selection of separate maintenance, divorce, and death (in case of the probate homestead) as the critical events for the reclassification. These events will not thenselves always provide an independent requirement of domicile as a basis for judicial action. Thus, in a separate maintenance action, there is no requirement that the plaintiff be domiciled in California. ${ }^{142}$ While there is such a requirenent for a California divorce plaintiff, ${ }^{143}$ division of the community property, and perhaps therefore of the quasi-community property as well, may be undertaken in a separate action following the divorce. ${ }^{144}$ There is apparently no requirement of domicile im California for such an action following divorce even though both spouses may have become domiciled elsewhere in the interim. Although cases involving the selection of a marital homestead from the quasi-community property are limited by the general homestead require-

${ }^{139}$ In re Thornton's Estate, 19 P.2d 778, 781 (1933). See Currie, Married Women's Contracts: A Study in Conflict of Laws Method, 25 U. C\#r. L. REv. 227, 260 (1958).

140 See text at notes 97-98 supra.

141 Currie, The Constitution and the Choice of Law: Governmental Interests and the Judicial Function, 26 U. CEn. L. REv. 9 (1958); Currie, The Constitution and the "Transitory" Cause of Action, 73 Harv. L. Rev. 36, 268 (1959) ; Currie \& Schreter, Unconstitutional Discrimination in the Conflict of Laws: Privileges and Immunities, 69 YALE L.J. 1323 (1960); Currie \& Schreter, Unconstitutional Discrintination in the Confict of Laws: Equal Protection, 28 U. C\#I. L. REv. 1 (1960).

142 See notes 150, 151 infra.

143 Ungemach v. Ungemach, $61 \mathrm{Cal}$. App. 2d 29, 142 P.2d 99 (1943); Crouch v. Crouch, 28 Cal. 2d 243, 169 P.2d 897 (1946) (dictum).

144 Percy v. Percy, 188 Cal. 765, 771, 207 Pac. 369, 371 (1922). 
ment that the parties reside upon the property selected, ${ }^{145}$ there is no analogous requirement for the setting apart of a probate homestead so long as the property is suitable for residential purposes. ${ }^{146}$ Since a probate homestead selected from the quasi-community property will be assigned to the surviving family absolutely, ${ }^{147}$ there is no requirement that they actually reside on the property after its selection.

How would the separate maintenance case arise? Imagine a husband and wife who have lived in New York ${ }^{148}$ since their marriage there some years ago. The husband has accuniulated a great deal of property during the marriage, all of it traceable to his earmings after marriage. His holdings consist of personal property, real property situated in New York, and real property in California. Suppose the husband informs his wife that he wants a divorce and then leaves for a two-week business convention in Los Angeles. Certainly it is conceivable that ingenious counsel for the wife might think of advising her to go to California lierself, serve her husband personally in Los Angeles, and file a suit there asking for separate maintenance and a division of the quasi-community property. Given a jurisdictional law that upholds the validity of service of process in an airplane during its transit of the appropriate state, such a situation does not seem far-fetched..$^{149}$

Research has failed to disclose a California separate maintenance case in which both parties were non-residents of the state. The cases are limited to situations in which the plaintiff, usually the wife, was a non-resident but the defendant was a resident. ${ }^{150}$ Dicta in at least one case indicates, however, that California would entertain such a case $;^{151}$ and a few other states have done so. ${ }^{162}$ The occurrence of the lrypothetical case, therefore, is with-

145 CaL. Crv. Code $\$ 1263$; e.g., Ellsworth v. Marshall, 196 A.C.A. 521, 16 Cal. Rptr. 588 (1961).

146 Estate of Firth, 145 Cal. 236, 78 Pac. 643 (1904); Estate of Noah, 73 Cal. 590, 15 Pac. 290 (1887).

147 Cax. Prob. Code $\$ \S 661,667$.

148 No attempt is made to state the New York law. That state's name is used only for convenience.

149 Grace v. MacArthur, 170 F.Supp. 442 (E.D. Ark. 1959). See generally Ehrenzweig, The Transient Rule of Personal Jurisdiction: The "Power" Myth and Forum Conveniens, 65 Y AIE L.J. 289 (1956). See also Transient Jurisdiction-Remnant of Pennoyer v. Neff: A Round Table, 9 J. PUв. L. 281 (1960).

150 Wynne v. Wynne, 20 Cal. App. 2d 131, 66 P.2d 467 (1937); Mattson v. Mattson, 181 Cal. 44, 183 Pac. 443 (1919); Hiner v. Hiner, 153 Cal. 254, 94 Pac. 1044 (1908) ; cf. Bullard v. Bullard, 189 Cal. 502, 209 Pac. 361 (1922). The same rule is applied in annulment cases. Millard v. Millard, 175 Cal. 797, 167 Pac. 394 (1917).

151 Bullard v. Bullard, 189 Cal. 502, 505, 209 Pac. 361, 363 (1922).

152 Martin v. Martin, 128 So. 2d 386 (Fla. 1961); Donigan v. Donigan, 236 Minn. 516, 53 N.W.2d 635 (1952); George v. George, 20 N.J. Misc. 41, 23 A.2d 599 (Chancery 1942); cf. Hopson v. Hopson, 221 F.2d 839 (D.C. Cir. 1955); Moller v. Moller, 11 Alaska 33, 66 F. Supp. 507 (D. Alaska 1946) ; Powell v. Powell, 40 Hawaii 625 (1954). Contra, see Anderson v. Anderson, 140 Okla. 168, 282 Pac. 335 (1929). 
in the realm of jurisdictional possibility. Moreover, the case is well within the wording of the new enactment. The California realty is expressly covered by the statute; so is any personal property owned by the husband, no matter where situated. Only the New York real property is outside the section. The sole question is whether California may constitutionally apply her statute to this set of facts. ${ }^{153}$ The alternatives are dismissal of the case in whole or in part or application of the law of New York. ${ }^{154}$

Despite a significant difference of opinion about the scope of the proposition, ${ }^{155} \mathrm{I}$ am persuaded by Professor Currie's analysis of the United States Supreme Court cases that a state court's choice of law is presently controlled by the United States Constitution and that such choice of law "will be upset under the Full Faith and Credit Clause or the Due Process Clause only when the state whose law is applied has no legitimate interest in its application." ${ }^{156}$ Following Currie's analysis, therefore, the problem becomes one of defining California's legitimate interests ${ }^{157}$ under the facts of

153 The constitutional problem posed here is significantly different from that discussed in the first section of this Article. The question there was whether California is constitutionally prohibited from dealing in a specified fashion with property acquired by persons who either were or had just become Cahifornia domicilaries. Cahfornia's responsibility to govern these persons and hence her governmental interest in them was unquestioned: the only problem was whether a property concept could be applied to them when that concept had not been co-existent with their acquisition of the property involved, either because they were not then Californians, or because the statute embodying the concept was not then in existence. The same problem can, and probably will, arise under the new statute. In addition to that problem, however, the hypothetical case poses another: application of the statute to persons physically present in the state and subject to the jurisdiction of its courts, but neither residing nor domiciled in Cahfornia. The statute could consistently be found constitutional in the first case but not in the second.

154 See generally EzRENZweIc § 82. In Latterner v. Latterner, 121 Cal. App. 298, 8 P.2d 870 (1932), however, the court characterized the Cahifornia realty as the husband's "separate" property, because he had acquired it with funds earned by him in Connecticut and Massachusetts. But the court refused to apply the law of those states regarding distribution of the husband's property on divorce, because the parties were reșidents of California and California law therefore governed the matter. See Brown, Conflict of Laws Between Community Property and Cominon Law States in Division of Marital-Properly on Divorce, 12 MERCER L. REv. 287 (1961).

155 EARENZWEIG $\S 4$, at $12, \S 9$, at 29-34 (1959).

156 Currie, The Constitution and the Choice of Law: Governmental Interests and the Judicial Function, 26 U. C표. L. REv. 9, 75 (1958). See also note 141 supra.

157 See generally in addition to the articles cited supra note 141, the following articles setting forth Professor Currie's general method: Currie, Married Women's Contracls: $A$ Study in Conflict-of-Laws Method, 25 U. CHI. L. REv. 227 (1958); Curric, Survival of Actions: Adjudication versus Automation in the Confict of Laws, 10 Stan. L. Rev. 205 (1958); Currie, On the Displacement of the Law of the Forum, 58 Corus. L. REv. 964 (1958); Currie, Notes on Methods and Objectives in the Confict of Laws, 1959 Duke L.J. 171 (DeNova transl., 14 Dirttro Internaztonare 335 (1960)); Currie, The Silver Oar and All That: A Study of the Romero Case, 27 U. CHr. L. REv. 1, 65-75 (1959) ; Currie \& Liebernian, Purchase-Money Morlgages and State Lines: A Study in Conflict-of-Laws Method, 1960 Doxe L.J. 1. The 
the hypothetical case. The method of doing so, as he has pointed out, is the familiar one of construction or interpretation. ${ }^{158}$

As $m$ other states, ${ }^{159}$ the separate maintenance decree in California does not dissolve the marriage, although it may be granted upon proof of a cause of action for divorce. ${ }^{180}$ A successful plaintiff may receive an order for temporary or permanent support and be granted the right to live apart from the defendant. No cause of action for divorce on the ground of desertion will result, unless the defendant later makes a bona fide offer of reconciliation that the plaintiff rejects. In this latter respect, Califorma's separate maintenance decree differs from the common-law decree of separation from bed and board. ${ }^{161}$ In addition to the two remedies of support and separation, simce 1917 California spouses in a separate maintenance action have been entitled to a division of the community property. ${ }^{162}$ The importance of this remedy was increased by the enactment in 1951 of Civil Code section 169.1 . That provision virtually terninated the community property system between the spouses after the entry of a separate maintenance decree by making the subsequent earnings and accumulations of both spouses separate property. Prior to that time, although the wife's earnings and accumulations becaine lier separate property whenever she lived "separate and apart" from her husband, ${ }^{163}$ his earnings and accumulations continued to feed the community estate. ${ }^{164}$ The court's division of the community property in separate maintenance cases is presently as complete as similar divisions on divorce. This is true even though the mutual obligations of support arising

theory has been criticized or commented upon by many scholars. Among them, the following stand out: Cavers, The Conditional Seller's Remedies and the Choice-of-Law Process, 35 N.Y.U. L. REv. 1126, 1136-38 (1960) ; Ehrenzweig, Choice of Law: Current Doctrine and "True Rules," 49 CALIF. L. REv. 240 (1961) ; Hill, Governmental Interest and the Conflict of Laws-A Reply to Professor Currie, 27 U. CHI. L. REv. 463 (1960); Leflar, Conflict of Laws, 1959 Survey of American Law, 35 N.Y.U.L. REv. 62 (1960); M. Traynor, Conflict of Laws: Professor Currie's Restrained and Enlightened Forum, 49 CALIF. L. REv. 845 (1961); R. J. Traynor, Is This Confilct Really Necessary?, 37 TExas L. REv. 657 (1959). Some of these criticisms have been answered in Currie, The Verdict of Quiescent Years: Mr. Hill and the Confict of Laws, $28 \mathrm{U}$. CEI. L. REv. 258 (1961).

158 Currie, Notes on Methods and Objectives in the Confict of Laws, 1959 DUKE L.J. $171,178$.

159 Brown, The Duty of the Husband to Support the Wife, in Setected Essays on Fasmley

LAw 810, 828-29 (1950).

160 CAx. CIv. Code $\$ 137$.

101 Monroe v. Superior Court, 28 Cal. 2d 427, 170 P.2d 473 (1946).

182 CaL. Crv. Code $\$ 146$.

163 CAL. Crv. Code $\$ 169$. As to what constitutes hiving "separate and apart," see Makeig v. United Sec. Bank \& Trust Co., 112 Cal. App. 138, 296 Pac. 673 (1931).

164 No similar provision existed for the husband prior to 1951. See 1 ARMrstrong 530-37 (1953). Civil Code $\$ 169.1$ has been "Spreckled." Jacquemart v. Jacquemart, 125 Cal. App. 2d 122, 269 P.2d 951 (1954). 
from the marriage can be finally terminated only by divorce $e^{105}$ and not by a separate maintenance decree. ${ }^{106}$

The delimitation of California's policy and the ascertainment of her interests in applying that policy to a separate maintenance action in her courts between non-residents differs according to whether support, separation, or division of the property is sought. The clearest case for application of California law is the judicial ordering of separation and support. Some states differ about what acts are sufficient to give rise to judicially ordered separation. ${ }^{107}$ Practically all agree, however, that separate maintenance actions may be maintained by non-resident wives against resident husbands to prevent evasion of a uniformly recognized duty of support. ${ }^{108}$ This principle should be applied even if both parties are non-residents. While care must be taken not to overlook differences that may be substantial, ${ }^{100}$ the policy of the domiciliary state should not be construed so narrowly as to produce a conflict with that of the forum when the underlying principle is common to both states. Currie's observation regarding the execution of wills and the requirement of consideration for contracts--that where the policies of all the states are substantially the same, those policies may be fulfilled by compliance with the formalities prescribed by any state $e^{170}-$

105 A decree of divorce that does not award alimony, if rendered with personal jurisdiction over both parties, terminates the obligation of support unless the court reserves jurisdiction to make an award in the future. Howell v. Howell, $104 \mathrm{Cal} .45,37 \mathrm{Pac} .770$ (1894); see Wilson v. Superior Court, 31 Cal. 2d 458, 464, 189 P.2d 266, 269 (1948). The obligation may also be terminated by a decree that modifies a prior award by eliminating it entirely and failing to reserve jurisdiction to reinstate the payments at a later time, McClure v. McClure, 4 Cal. 2d 356, 49 P.2d 584 (1935); and by a decree that grants alimony for a set time and fails to reserve jurisdiction to continue the payments thereafter, Long v. Long, 17 Cal. 2d 409, 110 P.2d 383 (1941); Tolle v. Superior Court, 10 Cal. 2d 95, 73 P.2d 607 (1937). These rules do not apply when the divorce is granted ex parte. Weber v. Superior Court, 53 Cal.2d 403, 348 P.2d 572, 2 Cal. Rptr. 9 (1960); Hudson v. Hudson, 52 Cal. 2d 735, 344 P.2d 295 (1959). See generally Annot., 43 A.L.R.2d 1387 (1955).

166 Monroe v. Superior Court, 28 Cal. 2d 427, 170 P.2d 473 (1946). The parties may, however, enter into an integrated property settlement agreement that is not modifiable, at least in the absence of an unaccepted offer of reconciliation or an actual reconciliation. Finnegan $v$. Finnegan, 42 Cal. 2d 762, 269 P.2d 873 (1954). The 1961 amendment to $\$ 139$ of the Civil Code may restrict integrated property settlement agreements in cases of divorce as well as separate maintenance to spouses who have no minor chlldren.

107 Crozier, Marital Support, 15 B.U.L. Rev. 28, 42-44 (1935), reprinted in SELECTED EsSAYS ON FAMIIY LAW 831, 846-48 (1950).

168 Ibid.; Greaney, Is New Hampshire a Haven for Husbands Avoiding Their Duty of Marital Support?, 3 N.H.B.J. 236 (1961) (collecting the statutes at 251-57); see Hiner v. Hiner, 153 Cal. 254, 257, 94 Pac. 1044, 1046 (1908) ("no one has ever deprecated the justice or wisdom of the provision except the delinquent husband limself"). Contra, Van Rensselaer v. Van Rensselaer, 103 N.H. 23, 164 A.2d 244 (1960).

109 Cf. M. Traynor, Conflict of Laws: Professor Currie's Restrained and Enlightened Forum, 49 CaLIF. L. Rev. 845, 856-62 (1961).

170 Currie, Notes on Methods and Objectives in the Conflict of Laws, 1959 DukE L.J. 171, $173,180-81$. 
seems applicable to separate maintenance cases. Moreover, the acceptance of this argument obviates further definition of California's interests. If no other state has an interest in having its particular law apphed, there is no "true" conflict of laws problenr, ${ }^{171}$ and the forum's law may be applied as a matter of convenience. ${ }^{172}$

California's interest in applying her law to effect a division of the quasicommunity property in a separate maintenance suit between non-residents stands on a different footing. There is no uniformity of policy among the states concerning the disposition of property in a separate maintenance decree. ${ }^{173}$ The application of California policy in this case, therefore, must be justified on the basis of her own interests. Because of the power traditionally accorded the state of situs to determine interests in real property, ${ }^{174}$ the strongest argument for application of California law probably exists with regard to division of the California real property. It must be recogmzed, however, that this position involves a rejection of the Restatement's suggestion $^{\mathbf{1 7 5}}$ that California define marital interests in the property by

171 M. Traynor, supra note 169 , at 845 .

172 Application of the forum's law under these circumstances must be distinguished from Currie's proposed application of the law of a distinterested forum when two conflicting foreign laws are assertedly applicahle and each foreign state has an interest in having its policy applied. See Currie, On the Displacement of the Law of the Forum, 59 CounM. L. Rev. 964, 1017-18 (1958). I do not agree with his reply to Professor Hill's objection that application of the law of the distinterested forum in such a case would be unconstitutional. See Hill, Governmental Interest and the Conflict of Lawes-A Reply to Professor Currie, 27 U. CHI. L. REv. 463, 478 (1960) ; Currie, The Verdict of Quiescent Years: Mr. Hill and the Confict of Laws, $28 \mathrm{U}$. CHI. L. REv. 258, 278 (1961). The cases that define the scope of full faith and credit to be accorded statutes in situations where the forum and a sister state have conflicting policies and interests refrain from compelling application of the sister state statute to displace the forum's statute only out of respect for the forum's policy and interest. E.g., Carroll v. Lanza, 349 U.S. 408 (1955); Watson v. Employers Liability Assur. Corp., 348 U.S. 66 (1954); Alaska Packers Ass'n v. Incustrial Acc. Comm'n, 294 U.S. 532 (1935). No such consideration exists to justify application of the policy of a dismterested state. Nor do I think that the result in New York Life Ins. Co. v. Head, 234 U.S. 149 (1914) (establisbing that application of a distinterested forum's policy to displace the different policy of an interested state violates the cue process clause) should be any different, if one assumes that New York as well as New Mexico is an interested state and that their policies are in conflict. I think the conclusion is inescapable that Missouri, as the distinterested forum, must apply one of the foreign laws if it takes the case at all. See M. Traynor, suppra note 169 , at 863 :

I cannot agree that the forum should either give up or apply its own policy by default. Abdication is irresponsible; courts are expected to reach their decisions rationally. A choice either way can be supported by the reasons used to support the rule in the state from which it is taken. Moreover, there is no forum interest to subordinate, so that an important element of Currie's "political" problem is absent.

173 See Annot., Adjudication of Property Rights in Action for Separate Maintenance, Surpport, or Alimony Without Divorce, 74 A.L.R.2d 316 (1960). See also Bolich, Acts Barring Property Rights, 40 N.C.L. REv. 175, 175-82 (1962).

174 See Lefrat, The Law of Confutct of Laws $\$ \S 22,140$ (1959).

176 Restatearent (Second), Conflict of Laws $\$ 238$, comment $a$ (Tent. Draft No. 5, 1959). 
looking to the law of the acquiring spouse's domicile at the time he acquired the consideration used to purchase the property. Moreover, prior to the 1961 enactment, the California courts had worked out a policy of permitting the state of domicile to determine for itself the interest of non-resident spouses in California land. ${ }^{176}$ This practice operated as a counterpart to California's policy of determining the interests of Califonia spouses in foreign land. ${ }^{177}$ So long as California did not directly affect title to the foreign land, she could safely pursue her policy without fearing that the much-criticized case of Fall $v$. Eastin ${ }^{178}$ would prevent the state of situs from extending recognition to California's determination of the equities. ${ }^{170}$ Although the doctrine thus far has been used only in divorce cases, no good reason appears for not extending it to separate maintenance cases as well. The new statute, however, if it is constitutional, is a legislative prohibition against voluntary recognition by California courts of the domiciliary state's determination according to its own law of the equities between the spouses in California land. Thus, the problem of assessing California's interests in the matter can no longer be ignored.

Despite an open invitation to do so, ${ }^{180}$ Professor Currie has not yet stated whether or to what extent he would apply his conflict of laws method to cases involving property. In full recognition of the danger of being summarily overruled, I venture to suggest that California's interest in determining the property rights of spouses in California real property must arise from her interest in the spouses and not merely from the location of the property in California. To regulate the property relations of married couples is to regulate a substantial element of the marriage. To base that regulation on physical control over the property seems unwarranted in view of the conceded interest of the domiciliary state in the marriage. Certain property regulations are appropriately provided by the law of the situs. Examples include regulating transfers of land and the recording of titles; prescribing tort habilities of non-resident landowners in order to protect local residents fron the maintenance of dangerous conditions on the land; and, within limits, establishing creditor priorities. No doubt analysis would disclose

176 E.g., Barber v. Barber, 51 Cal.2d 244, 331 P.2d 628 (1958); Estate of Warner, 167 Cal. 686, 140 Pac. 583 (1914).

177 E.g., Rozan v. Rozan, 49 Cal. 2d 322, 317 P.2d 11 (1957) ; Tomaier v. Tomaier, 23 Cal. 2d 754, 146 P.2d 905 (1944).

178215 U.S. 1 (1909).

${ }^{179}$ See cases cited note 177 supra; EHRENzweIg $\$ 58$; Currie, Full Failh and Credit to Foreign Land Decrees, 21 U. CHI. L. REv. 620 (1954); Currie, Justice Traynor and the Conflict of Laws, 13 Stan. L. Rev. 719, 743-44 (1961).

180 Leflar, Problems of Citizens of Community Property State Moving or Returning to Common Law State, ABA Section of Real Property, Probate and Trust Law, 1960 ProCEEDings Part $I$, at 16, 22, reprinted in 99 Trusts \& Estates 882, 886 (1960). 
other situations in which the sole fact of the location of land within the state provides a legitimate interest for the application of the state's policy. These situations, however, seem distinguishable from the creation of marital property rights for non-resident spouses in local land. The point is related to Currie's distinction between altruistic and legitimate interests. ${ }^{181} \mathrm{Cali}$ fornia may wish to extend to all married women the community property system, with its empliasis on the presumed equal contribution of both spouses to the acquisition of property. ${ }^{182}$ Such altruism, however, must not be undertaken at the price of defeating the legitimate interests of a state more closely connected with the parties than California. If this analysis is accepted, it follows that both the due process and full faith and credit clauses forbid the application of California law rather than the law of the marital domicile to the division of Cahfornia real property between nonresident spouses in a separate maintenance action. ${ }^{183}$

If the presence of real property in California does not constitutionally sustain application of California law under these circumstances, then it is doubtful that mere personal jurisdiction over the owner will sustain application of that law to divide his personal property according to community concepts. It appears, therefore, that Califorma's interests in the application of lier law to separate maintenance cases between non-residents should be carefully limited to the granting of separation and support. The 1961 enactment should not be apphied to such cases at all. If California undertakes to dispose of the California realty, she should do so according to the law of the only interested state-New York.

California does, however, have an interest in dividing the property according to commumity concepts when either or both parties to a separate mamtenance action are California domiciliaries. ${ }^{184}$ The same is true of divisions in Califorma divorce actions, since California is among the majority of American states that require domicile as a basis for local jurisdiction in

181 Currie \& Schreter, Unconstitutional Discrimination in the Confict of Laws: Privileges and Immutnities, 69 Yate L.J. 1323, 1362-68 (1960). The Supreme Court has held that the restriction of community rights in local property to married women residing in the state and women married in the state does not violate the privileges and immunities clause of article IV. Conner v. Elliott, 59 U.S. (18 How.) 591 (1855).

182 Cahifornia's largesse may be unappreciated by its proposed recipients. See Powell, Conmmuity Property-A Critique of Its Regulation of Intra-Family Relations, 11 WASH. L. Rev. 10 (1936), reprinted in SeIected Essays on FAMmLY LAW 525 (1950).

183 See Currie \& Schreter, supra note 181, at 1365-66. The statement in the text does not, of course, prohibit the California court from placing a hen against the real property as security for the husband's payment of separate maintenance. Such an action does not constitute the division of quasi-comnunity property.

184 See generally Note, Marital Property and Migratory Divorce, 3 Stax. L. Rev. 622 (1951). 
divorce. ${ }^{185}$ It has been suggested, however, in a study conducted by Professor Marsh, that even in these cases the statute is unconstitutional insofar as it requires an equal division of the quasi-community property instead of permitting the court to order an equitable division. ${ }^{186}$ When the divorce or separate maintenance decree is granted on the ground of adultery, incurable insanity, or extreme cruelty, the court is permitted to divide the community and quasi-community property as it deems just, having regard for the facts of the case and the condition of the parties. ${ }^{187}$ But when the decree is granted on the ground of desertion, neglect, habitual intemperance, or conviction of a felony, both the community and quasi-community property must be divided equally between the parties. ${ }^{188}$ Since the overwhelming majority of separate maintenance and divorce decrees in California are granted for extreme cruelty, ${ }^{189}$ the constitutional objection applies only to a small number of cases. Moreover, the objection is asserted only when the statute requires that one-half of the erstwhile common-law property acquired by the successful plaimtiff be awarded to the losing non-acquiring spouse, not when the acquiring spouse is the losing party. Assume, for example, that the wife is the successful plaintiff in a divorce action brought on the ground of her husband's desertion and that she is the bread-winner of the family. The objection is that an award to her husband of one-half the property acquired by her in a common-law state from her earnings in that state is so unreasonable and arbitrary that it violates the due process clause. If, instead, the divorce is granted to the husband for his wife's desertion, no objection would be raised against the award.

It is admittedly difficult to justify a reclassification of common-law property according to community concepts as incidental to California's legitimate interest $i \mathrm{~m}$ the general regulation of the marriages of persons who

185 See note 143 supra. See generally Harris \& Cardozo, Divorce Without Domicile: Two Viezes on the Virgin Island Statute, 39 CORNELL L.Q. 293 (1954); Leflar, Conflict of Laws and Family Law, 14 ARK. L. REv. 47 (1959-60) (collecting the minority cases and statutes that dispense with the domicile requirement) ; Powell, And Repent at Leisure, 58 HARv. L. REv. 930 (1945). As to the related problem of alimony awards following ex parte divorces, see Stumberg, Foreign Ex Parte Divorces and Local Claims to Alimony, 34 WASH. L. Rev. 15 (1959). See also Vanderbilt v. Vanderbilt, 354 U.S. 416 (1957); Hudson v. Hudson, 52 Cal. 2d 735, 344 P.2d 295 (1959) ; Loeb v. Loeb, 4 N.Y.2d 542, 152 N.E.2d 36, 176 N.Y.S.2d 590 (1958); EHRENZWEIO $\$ 81$; Comment, State Law Problems in Adopting the Divisible Divorce Theory, 12 Stax. L. REv. 848 (1960) ; Note, Conflict of Laws: Divisible Divorce in California, 48 CALF. L. REv. 303 (1950).

186 LAW COMMa'v STUDY at I-33, I-34.

187 CaL. Crv. CoDE $\S 146(1)$. The section has been construed to mean that the prevailing party must be awarded at least half of the community property, if not more. 1 ARMstrono $791-96$.

188 CAL. CTV. CODE $\S \S 146(2), 92$.

180 Law Comas's Studx at I-8, citing Livingstone, Some Practical Phases of Divorce Litigation, in FAMTIX LaW FOR CaLIFORNIA LawYers 32 (Cont. Ed. Bar 1956). 
become her domiciliaries ${ }^{190}$ if the property aspects of that regulation are not imposed until the marriages are terminated or suspended. ${ }^{191}$ Nevertheless, the legislature has determined that an equal division of community and quasi-community property is equitable in all cases except those in which the decree is granted for adultery, extreme cruelty, or incurable insanity. ${ }^{192}$ A difference in property division turning on a distinction drawn between a divorce for extreme cruelty and one for habitual intemperance may be questioned on logical grounds. But to constitute a deprivation of due process when measured against the police power of the state, the distinction presumably must be arbitrary and unreasonable as well as illogical. ${ }^{193}$ The constitutionality of the statute in determining the division of community property has never been questioned. This fact cannot be put aside with the comment that where community property is involved each spouse is considered the "owner" of "one-half" the property from the time of its acquisition. ${ }^{194}$ The equal division statute was enacted in 1872 and applied to all divorces. ${ }^{195}$ The present distmction based on the ground upon whicl the divorce was granted was enacted by the amendment of $1873-1874 .{ }^{196}$ Yet the wife was not considered an "owner" of the community property in any sense until $1927 .^{197}$ Nor is the argunient persuasive today that the fixed share provision should be used only to award the "guilty" spouse's property to the "innocent" spouse. ${ }^{198}$ The concept of fault in divorce, widely recoguized as inharmonious with the realities of marriage, ${ }^{199}$ has been largely abandoned in California. Since 1951, California statutes have referred to spouses "against whon" a divorce has been granted, ${ }^{200}$ not to "guilty" or "innocent" spouses. And since 1952, it has been Califorma law that, upon a proper showing, divorces may be granted to both spouses in the same action. ${ }^{201}$ Under these circumstances there are no "guilty" or "innocent" spouses even in the legal sense of the words. In such cases the community

190 See Armstrong, "Prospective" Application of Changes in Community Property Control

-Rule of Property or Constitutional Necessity?, 33 CALIF. L. REv. 476, 496 (1945).

191 See text at note 135 supra.

192 Cax. Crv. Code $\$ 146$.

193 Armstrong, supra note 190, at 495-96.

194 Law Conar's STUDY at I-33.

195 West's Ann. CaI. Crv. Code, Historical Note to § 146, at 636 (1954).

196 AMrENDMENTS To THE Codes 1873-1874, at 191-92. The unequal division in cases of divorce on the ground of incurable insanity was added in 1941. Cal. Stat. $1941 \mathrm{ch} .951$, at 2547. Until that date insanity was a defense to divorce.

197 CaL. Crv. Code § 161a; see text at notes 58-78 supra.

198 Law CoMñ's STUdr at I-34.

199 Bradway, The Myth of the Innocent Spouse, in Setected Essays on Fammx Law 937 (1950) ; Rutman, Departare from Fault, 1 J. FAMrrx I. 181 (1961); Silving, Divorce Without Fanlt, in Selected Essays on Family Law 907 (1950).

200 CAL. CTv. Code $\S \S 139,146$.

201 De Burgh v. De Burgh, 39 Cal. 2d 858, 250 P.2d 598 (1952). 
property is divided equally irrespective of the ground upon which the divorces are granted. ${ }^{202}$ In view of California's often stated policy against using her divorce laws as instruments of punishment, ${ }^{203}$ the equal division statute seems without constitutional defect when considered as a legislative determination of the equities between the spouses.

Moreover, when both spouses are California domiciliaries and both are before the court, the new statute may have stopped short of its full potential by excluding real property located in other states. California presently determines the equities between the spouses in foreign land acquired with community funds. ${ }^{204}$ The only difference in the quasi-community property case is that the land was acquired with common-law funds while the spouses were domiciled in a common-law state. If the thesis is accepted that California may constitutionally reclassify property brought into the state by persons who become domiciled there, then it follows that California may reclassify property left behind. The justification for doing so in both cases rests on California's interest in the spouses, not in their property. In this regard, the 1961 amendment of Civil Code section 164 appears unwise. The amendment limits the pre-1917 definition of community property found in that section to real property located in California and removes the 1917 amendment lield unconstitutional in Estate of Thornton. The pre-1917 definition would have operated as a legislative declaration of policy sustaining the approach of California cases holding that foreign real property acquired by California spouses with community funds may be equitably divided as if it were community property. ${ }^{205}$ Moreover, the definition would be helpful to courts at the situs that wish to apply California law. ${ }^{208}$ The geographical limitation should be removed from the definitions of both community and quasi-community property. Limitations based upon the scope of California's legitimate interests in each case can then be developed by the courts.

Application of the quasi-community property statute to California real property may also arise in Califorma as an outgrowth of divorce actions in

202 Id. at 874,250 P.2d at 607.

203 Cf. id. at 863-64, 250 P.2d at 600-01; Hull v. Superior Court, 54 Cal. 2d 139, 145-46, 352 P.2d 161, 164, 5 Cal. Rptr. 1, 4-5 (1960).

204 Rozan v. Rozan, 49 Cal. 2d 322, 317 P.2d 11 (1957) ; Tomaier v. Tomaier, 23 Cal. 2d 754, 146 P.2d 905 (1944).

205 Ibid.

206 This point was suggested by my colleague, Professor Rex A. Collings, $\mathrm{Jr}$, who is not as confident as the Law Revision Commission appears to be of the ability of a foreign court to apply the California tracing doctrine, particularly without the help of the Commission's Recommendations. See LAW Comor's STUDY at I-12, I-13 n.9; compare Wallack v. Wallack, 211 Ga. 745, 88 S.E.2d 154 (1955), discussed in Brown, Confict of Laws Between Contmutnity Property and Common Law States in Division of Marital Propery on Divorce, 12 MERcer L. REv. 287 (1961). 
other states. Assume that our New York husband procured a divorce in that state from his wife. What disposition will be made of the California real property in that proceeding? Without attempting to predict what New York would actually do in such a case, let us assume that she would either decide the equities between the parties in the California land according to New York law, expecting California to honor her decision; or refuse to dispose of the land, leaving that task for the California courts. In either case, further proceedings in California will be necessary-proceedings for which there is no requirement of domicile.

As we have seen, California's pre-1961 practice ${ }^{20 \tau}$ of deferring to the state of domicile in such cases has been rejected by the new enactment. The constitutional conclusion reached in connection with the separate maintenance case, however, will prevent application of the new statute in the New York divorce case as well, unless a distinction can be found to support a difference in California's interests in the two cases. Clearly no such distinction exists when New York has previously adjudicated the respective equities between the parties in the California land. In similar cases the California courts have stated that they will recognize the sister state's adjudication on the theory that it is entitled to full faith and credit. ${ }^{208}$ If the United States Supreme Court sustains the California courts on this point, then the statute is plainly unconstitutional as applied to the New York divorce case, since it in effect directs a denial of full faith and credit to the New York judgment.

However, if New York, the state of domicile, defers to California, the state of situs, the situation is not so clear. It is not lielpful to point out that New York has not fully understood her own interests in the matter, for California's legislatively declared policy must be effected unless the federal constitution forbids. The previous discussion of California's altruistic interests is relevant to this case. Professor Currie has taken the position that a state's altruistic interests are constitutionally sufficient to sustain application of the forum's law only when that application does not defeat the direct interest of another state. ${ }^{200}$ If the action had been brought in California first, the due process and full faith and credit clauses would have prevented the application of her law merely to advance an altruistic interest. ${ }^{210}$ As things now stand, however, New York has chosen not to advance her concededly legitimate interests. I cannot believe that a proper regard for $\mathrm{New}$

207 E.g., Barber v. Barber, 51 Cal. 2d 244, 331 P.2d 628 (1958).

208 Id. at 247,331 P.2d at 630-31; cf. Rozan v. Rozan, 49 Cal. 2d 322, 330-31, 317 P.2d 11, 16 (1957).

209 Currie \& Schreter, Unconstitutional Discrimination in the Conflict of Laves: Privileges and Immnonities, 69 YALE L.J. 1323, 1360-61 (1960).

210 Id. at 1365-66. 
York's interests compels California to stay the case. After all, California has a direct interest in preserving for local citizens the marketability of titles to California land, to say nothing of her interest in the timely administration of justice between litigants in her courts. Furthermore, for California to apply New York law seems improper in view of the specific language of the quasi-community property statute. If application of California law is to be sustained on this basis, however, the position must be defined with care. For example, it is important to determine the effect in the rendering state of a divorce decree that does not adjudicate rights of the spouses in foreign land. ${ }^{211}$ If the property can be divided independently of a divorce in a later New York suit, ${ }^{212}$ then California cannot proceed on the assumption that New York has failed to recognize her own interests. It is only when the New York decision not to divide the property is final that California is justified in applying her own law, even though New York's decision to abstain was motivated by a misplaced respect for Fall $v$. Eastin. ${ }^{213}$

Cahifornia statutes governing selection of the inter vivos marital homestead contain a built-in limitation for the quasi-conımunity property statute in the requirement that the spouses must reside upon the declared premises. ${ }^{214}$ As the Law Revision Commission's recommendation indicates, ${ }^{215}$ application of the new statute to California real property traceable to common-law funds acquired by the husband creates no new power in the wife. She had previously been permitted to declare a niarital homestead on her husband's separate property, ${ }^{218}$ including property traceable to his commonlaw acquisitions, ${ }^{217}$ without his consent. The only new factor introduced by the quasi-community property statute relates to devolution of the marital homestead after the husband's death. Previously, a marital homestead declared by the wife without her husband's consent on property traceable to his acquisitions in a common-law state, ${ }^{218}$ like a similar homestead declared

211 In California, community property not disposed of by a divorce decree becomes property held by the spouses as tenants in common. E.g., Daut v. Daut, 98 Cal. App. 2d 375, 220 P.2d 63 (1950); Calhoun v. Calhoun, 81 Cal. App. 2d 297, 183 P.2d 922 (1947). If the ground of the divorce is adultery, extreme cruelty, or incurable insanity, the spouses are tenants in common of undetermined interests. If the divorce is granted on other grounds, they each own an undivided one-half interest in the former conmunity property. 1 ARMSTRoNo 844.

212 See Brown, supra note 206.

218215 U.S. 1 (1909); see note 179 supra. For an illustration of such respect, see Cummings v. Cummings, $138 \mathrm{Kan} .359,26$ P.2d 440 (1933), reporting the action of the Texas court. 214 CAL. Crv. CoDE § 1263. E.g., Ellsworth v. Marshall, 196 A.C.A. 521, 16 Cal. Rptr. 588 (1961). See generally Comnent, Creation of the Homestead and Its Requirements, 26 CaLrF.

L. REv. 241 (1938).

215 LAw COMM'N Study at I-10, I-11.

216 CAt. Crv. Cone $\S \S 1238,1239$; Magneson v. Pacific Mfg. Co., 26 Cal. App. 52, 146 Pac. 69 (1914).

217 Estate of Burrows, 136 Cal. 113, 68 Pac. 488 (1902).

218 Ibid. 
on his separate property, ${ }^{219}$ passed by his will or descended to his heirs, subject to the power of the probate court to set the homestead apart to the wife or children for a limited period. Under the 1961 enactment, these homesteads, like community property marital honesteads, will vest absolutely in the surviving spouse. ${ }^{220}$ The change raises no constitutional problem, however, for the husband's hfetime powers are not affected and he acquires no "vested right" in the laws relating to descent and testamentary control of property. ${ }^{221}$

On the other hand, the new enactment does create in the husband the power of declaring a marital homestead without his wife's consent upon quasi-community property traceable to her acquisitions. Heretofore such property would presumably have been classified as the wife's separate property, and the husband could not have declared a marital homestead without her consent. ${ }^{222}$ This provision will limit the wife's lifetime control over the property, since she must have her husband's consent to convey or encumber the homestead. ${ }^{223}$ Nevertheless, California's interest in the regulation of marriages in a uniform fashion seems to justify this restriction of the common-law wife's powers, which places her on a par with California wives. ${ }^{224}$ The survivorship element applicable to the husband's quasi-community property will apply in the wife's case as well, and the same argument made there will prevent any constitutional difficulty.

Under California law, the right of the surviving family to have a probate homestead set apart is a limitation upon the decedent's power of testamentary control. If no marital homestead was declared and the probate honiestead is set apart from community property, the family takes the homesteaded property in fee. ${ }^{225}$ If separate property is used, the homestead may be set apart to the family for a limited tinie only; ${ }^{226}$ the fee interest in such a case belongs to the decedent's devisees or heirs, subject to administration. ${ }^{227}$ Prior to the revision of Probate Code section 201.5 in 1957, real property in California acquired with common-law funds was treated like separate property for the purpose of setting apart a probate homestead. ${ }^{228}$ After 1957, probate homesteads selected from so-called "section

219 CaI. Prob. Code $\$ 663$.

220 Ibid.

221 See generally Estate of Thornton, I Cal. 2d 1, 5, 33 P.2d 1, 3 (1934) (Langdon, J., dissenting). This opinion apparently motivated the enactment of Probate Code $\$$ 201.5.

222 CaI. CIv. CODE § 1239.

223 CaL. Civ. Code $\$ 1242$.

224 See text at notes 132-33 supra.

225 CAL. PROB. CODE $\$ \S 661,667$.

226 Cat. Prob. Code $\S 661$.

227 Ibid.

228 Estate of Niccolls, 164 Cal. 368, 129 Pac. 278 (1912). 
201.5 property" were treated like homesteads selected from community property. ${ }^{229}$ No problem of whether surviving spouses could be awarded probate homesteads in the California real property of their non-domiciliary deceased spouses arose under section 201.5, since it applied only to persons who died domiciled in California. That problem does arise, however, under the quasi-commumity property statute, for the new enactment has replaced the reference to section 201.5 property in the probate homestead section with a reference to quasi-community property, ${ }^{230}$ which, as we have seen, is not himited to domiciliaries. It is thus necessary to assess California's interests in applying her probate homestead law to cases involving nondomiciliary decedents.

If the decedent died domiciled elsewhere, but his spouse was a California resident, California's interest in affording the protection of a probate homestead to the survivor is plain. Indeed, California has already so construed her family allowance statute, ${ }^{231}$ and the principle there stated applies as well to probate homestead cases. ${ }^{232}$ Moreover, a New York decision reports the setting apart of a probate homestead by a California court to the minor daughter of a New York decedent. ${ }^{233}$ The case report does not state whether the daughter was a California resident, but one may infer that she was. Her mother, who was separated from the decedent, alleged in her petition for letters of admimistration covering the California property that she and her daugliter were residents of Los Angeles. ${ }^{234}$ The probate court must have found this allegation true, for it appointed her administratrix-a position open only to bona fide residents of California. ${ }^{235}$ Since the decedent had been ordered to pay his wife a monthly sum for the daughter's support, it may be surmised that the daughter's presence in California was pursuant to a custody order. Under these circumstances, California had an interest in setting apart a probate homestead for the daughter.

When both the decedent and his family are domiciled elsewhere, however, the situation is different. No California case has limited the probate homestead statute to domiciliaries, ${ }^{236}$ and it nay be conceded that Califor-

229 Cal. Prob. Code $\$ 661$.

230 Ibid.; Selected 1960-1961 California Legislation, 36 Cax. S.B.J. 674 (1961).

231 Estate of Foreman, 16 Cal. App. 2d 96, 60 P.2d 310 (1936).

232 Estate of Brooks, 28 Cal. 2d 748, 171 P.2d 724 (1946).

${ }^{233}$ In $r e$ Van Zandt's Estate, 255 N.Y. Supp. 359, 142 Misc. 663 (Surr. Ct. 1931).

234 Estate of Newton Van Zandt, Los Angeles County Superior Court Probate File No. 62342, Petition for Letters of Administration, p. 2, lines 5-14 (May 29, 1928).

235 Cal. Prob. Code $\$ 420$.

${ }^{236}$ The only case found that even raises the point is Estate of Green, 1 Coffey's Probate Decisions 444 (Cal. 1888). In that case the decedent and his wife were pbysically present in England at the time of his death. The court found, however, that the surviving wife was a resident of California at the time she apphied for a probate homestead. In two other California cases involving claims of non-domiciliary widows to Cahfornia real property that had been 
nia has the constitutional power even in this case to set apart a probate homestead for the family. The discussion of altruistic interests put forth in connection with separate maintenance and divorce is once again relevant. But the assertion of California's altruistic interests may interfere with the direct interests of the state of domicile in this case. The probate homestead may be granted to the surviving family against the claims of other persons: creditors of the estate, the decedent's devisees, or the intestate heirs. Whether the law of the decedent's domicile makes no similar provision for the family, or whether it provides similar relief as to property there located, California's direct interests are not involved. It is submitted that California should yield to the law of the domicile at death in this situation and refuse to award a probate homestead in the California real property.

This suggestion is reinforced by Probate Code section 201.6, which applies when a married person domiciled elsewhere dies leaving a valid will disposing of Cahifornia real property that is not community property. In such a case, the surviving spouse "has the same right to elect to take a portion of or interest in such property against the will of the decedent as though the property were situated in the decedent's domicile at death." The section thus establishes California's policy of applying the law of the decedent's domicile to determine the marital rights of the surviving spouse in non-community real property. Since it is not limited to property owned by deceased Californians, the defimition of quasi-community property overlaps with the definition of section 201.6 non-community property in probate homestead cases. The policy of section 201.6 would nevertheless support the refusal of a Cahifornia court to set apart a probate homestead from quasi-community property in favor of a non-domiciliary surviving family, unless directed to do so by the law of the domiciliary state. If applied literally, of course, section 201.6 would support the same result even if the surviving family were California domiciliaries. As we have seen, however, the case law wisely limits California's subjugation of her own interests to those of the decedent's domicile in this regard, so that a probate homestead will be set apart under such circumstances. ${ }^{237}$

\section{CONCLUSION}

Like Currie's hypothetical legislator, ${ }^{238}$ the Law Revision Commission seems to have assumed in making its recommendation for the quasi-com-

owned by their non-domiciliary deceased husbands, the briefs disclose that no probate homestead was requested. Estate of Arms, 186 Cal. 554, 199 Pac. 1053 (1921); Estate of Warner, 167 Cal. 686, 140 Pac. 583 (1914). But see Estate of Mitchell, 97 Ohio App. 443, 127 N.E.2d 39 (1954). See generally Annot., 51 A.L.R.2d 1026 (1957).

237 See notes 231-34 supro.

238 Currie, Married Women's Contracts: A Study in Confict-of-Lanes Method, 25 U. CEr. L. REv. 227, 230-31 (1958). 
munity property statute that it was proposing a law only for persons who become Californians. If the courts limit the statute to Californians, it should be held constitutional despite the shadow of Estate of Thornton. If the statute inspires reexamination of the Thornton case in light of its dependence on the doctrine of Spreckles v. Spreckles, the legislature will have taken the first step toward achieving its fullest constitutional potential in this area. For such a reexamination hopefully may result in the prospective overruling of Spreckles and the consequent elimination of even the shadow of Thornton. The way will then be clear for the legislature to establish a single inarital property law for all Californians.

Despite these achievements, however, the statute's failure to identify the persons it seeks to govern raises a serious question about the legislative process. The observation that practically all legal problems are potentially conflict of laws questions has become trite. But it is particularly apt in this case, since the problem of applying community concepts to property acquired in common-law states is as much a conflict of laws question as one of marital property. Yet the enactment sought to deal only with the central problein, ignoring other conflict of laws difficulties that lurked on the periphery. Surely, when the conflicts problems were so apparent, the Cominission should have heeded Currie's suggestion ${ }^{239}$ that a statute should expressly indicate the limits of its applicability. Drafting should be undertaken only after a careful analysis of the state's policy and interests. A forthright legislative definition of the state's policy and interests will not only materially aid the courts of the enacting state, but also will aid the courts of sister states in deciding whether the enacting state wishes to assert an interest in having the statute applied in a given case. By ignoring these problems, the Commission has left their solution to an already over-burdened judicial system. Although the California legislature can safely commit the delimitation of its new enactment to a state supreme court sensitive to the problems of conflict of laws cases, other legislatures may not be so fortunate. 